\title{
A local-scale approach to estuarine flood risk management
}

Paula Freire | Alexandre O. Tavares | Luís Sá | Anabela Oliveira | André B. Fortunato | Pedro P. dos Santos | Ana Rilo| João L. Gomes | João Rogeiro| Rui Pablo | Pedro J. Pinto

Received: 23 March 2016 / Accepted: 31 July 2016

Abstract: New challenges in flood risk management are raised by climate change and land-use development. These challenges are particularly complex in estuarine and coastal systems, where different hazard sources interact in a dynamic socio-economic context. This paper presents an innovative approach to support flood risk management in estuaries. The approach, developed at a local-scale basis, is applied in the case study of the Tagus estuary (Portugal). The methodology is supported by the regional framing of the study area and integrates hazard, exposed elements, territorial vulnerability and risk assessments

\author{
Paula Freire \\ pfreire@lnec.pt \\ Alexandre O. Tavares \\ atavares@ci.uc.pt \\ Luís Sá \\ luis.sa@prociv.pt \\ Anabela Oliveira \\ aoliveira@lnec.pt \\ André B. Fortunato \\ afortunato@lnec.pt \\ Pedro P. dos Santos \\ pedrosantos@ces.uc.pt \\ Ana Rilo \\ arilo@Inec.pt \\ João L. Gomes \\ jlgomes.web@gmail.com \\ João Rogeiro \\ jrogeiro@lnec.pt \\ Rui Pablo \\ rui.pablo@cm-seixal.pt \\ Pedro J. Pinto \\ pedrojpinto@gmail.com
}


considering different climate scenarios. Through the involvement of the various risk management dimensions, the results allow the definition of a new decision-making supporting framework for emergency and land-use planning. At the emergency level, the results include a WebGIS interface providing an early warning system for the locations with highest risk of flooding and the definition of emergency planning guidelines. A set of flood adaptation actions based on land-use and occupation measures are recommended to increase resilience in face of flooding and future sea level rise. The institutional capacitybuilding is achieved through the availability of information and tools that can effectively support decision-making. Additionally, the outcomes contribute to better understand flood risk in estuaries and to strengthen its prevention, preparedness and response, priorities defined in the Sendai Framework for Disaster Risk Reduction 2015-2030.

Keywords: Flooding, Estuaries, Territorial vulnerability, Extreme events, Early warning, Decision-making

\section{Introduction}

Floods can have devastating consequences on the economy, environment and people with high associated costs. In Europe, it is reported that between 1998 and 2009, flooding and storms were the most costly hazards, with 1126 fatalities and the displacement of about half a million people, with overall losses associated with floods of $€ 52$ billion (EEA 2010). More recently, the floods of June 2013 led to an estimated $€ 12$ billion in economic losses across nine EU Member States (EC 2014). Flood drivers and impacts will be affected by future climate change in combination with land-use changes and water management practices (Simonovic' 2012). The observed extreme flood losses in Europe are expected to more than double in frequency by 2050 under future climate change and socio-economic development (Jongman et al. 2014). Over the last decades, flood management policy has shifted from providing flood hazard protection measures towards a more adaptive and integrated flood risk management approach (Ward et al. 2013; Kousky and Shabman 2015). Aiming to reduce the adverse consequences of flood risk in a climate change context, the EU Floods Directive (Directive 2007/60/EC) creates a common framework to establish flood areas, flood risk maps and flood risk management plans. Management plans should focus on prevention, protection and preparedness, including flood forecasts and

1 Estuarine and Coastal Zones Unit, National Civil Engineering Laboratory, Av. do Brasil 101, 1700-066 Lisbon, Portugal

2 Earth Sciences Department and Centre for Social Studies of the University of Coimbra, Coimbra University, 3001-401 Coimbra, Portugal

3 National Authority for Civil Protection, Av. do Forte em Carnaxide, 2794-112 Carnaxide, Portugal

4 Information Technology in Water and Environment Research Group, National Civil Engineering Laboratory, Av. do Brasil 101, 1700-066 Lisbon, Portugal

5 Centre for Social Studies of the University of Coimbra, Coimbra University, 3001-401 Coimbra, Portugal

6 Civil Protection Service of Seixal Municipality, Alameda dos Bombeiros Volunta'rios 45, 2844-001 Seixal, Portugal 
early warning systems, and the promotion of sustainable land-use and water management practices. Nevertheless, few studies address adaptive and integrated systems of flood risk management at a city level (Ward et al. 2013).

Estuaries are among the coastal systems where the flood risk is highest, due especially to the extensive occupation of adjacent low-lying areas, which host about $70 \%$ of the largest cities in the world (Morris et al. 2013). This risk is likely to increase with climate change effects, such as sea level rise (IPCC 2014), and the people and economic assets located on its margins keep increasing. The social and physical impacts of recent events, such as in 2005 the hurricane Katrina in New Orleans (Miller et al. 2015), in 2010 the storm Xynthia along the French coast (Bertin et al. 2014; Andre' et al. 2013) and in 2012 the hurricane Sandy in New York (Aerts et al. 2013), draw attention to the need to improve risk management in those systems. Risk assessment and management in estuaries raises several challenges related to the interaction of different hazard sources, such as tides, river flows, wind and waves, and the socioeconomically dynamic nature of these systems. This complexity requires multi-level approaches, implying a multi-scale assessment of the existing conditions to address specific information demands (Santos et al. 2015).

This paper aims at presenting an integrated approach to support flood risk management in transitional systems taking into account different levels of the decision-making process, emergency and land-use and occupation planning considering different climate scenarios. This approach is applied at a local scale, identified in previous studies through the hazard, exposure and territorial vulnerability assessments at a regional scale (Tavares et al. 2015; Freire et al. 2015).

The study area, the municipality of Seixal, is located in the southern margin of the Tagus estuary (Portugal) (Fig. 1) and is one of 11 municipalities of the Metropolitan Area

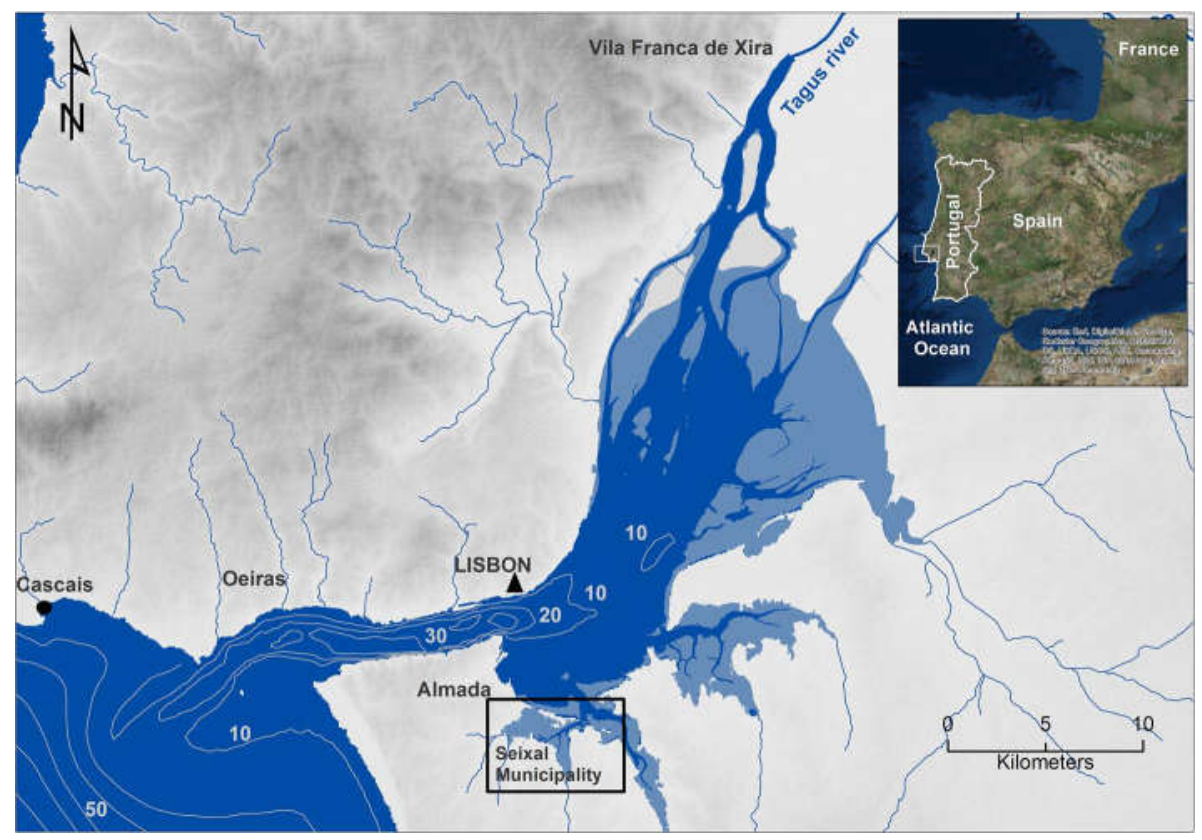

Fig. 1 Location of the study area in the Tagus estuary. Location of monitoring stations mentioned in the text: Cascais tidal gauge (circle) and Lisboa Geofi'sico meteorological station (triangle) 
of Lisbon that constitute the estuarine marginal area. About 1.6 million of inhabitants, mostly concentrated in the western and northern sides, live along the estuary margins (Tavares et al. 2015). The waterfront of the Seixal Municipality was particularly affected by past floods, showing specific territorial vulnerability characteristics. Local and regional planning instruments are now required to incorporate risk mapping and more detailed characterization of flood-prone areas, partially as a consequence of the transposition of the Floods Directive to the national law. Being recent changes, the experience in their implementation and influence over management decisions at the local level is still limited. Nevertheless, a few recently revised Portuguese municipal land-use plans, such as those of Lisbon, Coimbra and Seixal, already include detailed flood risk maps. These plans come at a time when municipalities are being strongly encouraged by regional planning commissions towards the definition of conservative expansion areas for urban centres, in stark contrast to the very optimistic urban perimeters of only a decade ago.

The paper is organized as follows. In Sect. 2, the framework of the study area in the Tagus estuary context is presented, addressing the historical past flood events, the hazard sources (extreme water levels) and the territorial vulnerability. The flood risk management approach followed in the present study is described in Sect. 3. In Sect. 4, the results of the hazard, exposed elements, vulnerability and risk assessment for the study area are presented. Based on these results, a decision-making supporting framework is presented and discussed in the following section, at both emergency and land-use planning levels. Finally, the conclusions are addressed in Sect. 6.

\section{Framing the study area in the Tagus estuary context}

\subsection{Historical flood events}

A previous study, based on a regional database (r_DB) of historical flood occurrences (Rilo et al. 2015), revealed that the probability of occurrence of one or more flood events in the Tagus estuarine margins in one year is $26 \%$. These authors defined an "occurrence", as a geographically defined place affected by estuarine flooding, independently of its severity, which is described or appears in selected data sources; the occurrences can be grouped into a single event following a temporal criterion. Based on Rilo et al.'s (2015) results and updated data in the present paper, 235 occurrences were registered along the estuary margins between 1865 and 2013, related to 45 flood events. These flood occurrences are widely distributed along the margins between Vila Franca de Xira (the downstream limit of freshwater floods) and Oeiras (at the sea entrance), with high incidence on the Lisbon and Oeiras municipalities (Fig. 1). The maximum number of events recorded in one year was three, in 1936 (Fig. 2), and the years with the largest numbers of occurrences were 1945 (25), 1937 (24), 1941 and 2010 (15 each).

The frequency of the historical flood occurrences analysed is higher between 1930 and 1950, showing a decrease thereafter (Fig. 2). That period overlaps intense rainy years, during which severe urban inundations were registered (Oliveira and Ramos 2002). Between 1950 and 1970, the Tagus hydrological regime suffered major changes due to the construction of more than 140 dams in the river basin; after 1970, the flow regime of the Tagus river in Portugal depends mostly on the operation of the Alca ntara dam in Spain, and a clear downward trend in the maximum flood flow and flood frequency is observed (ARH do Tejo 2011). 


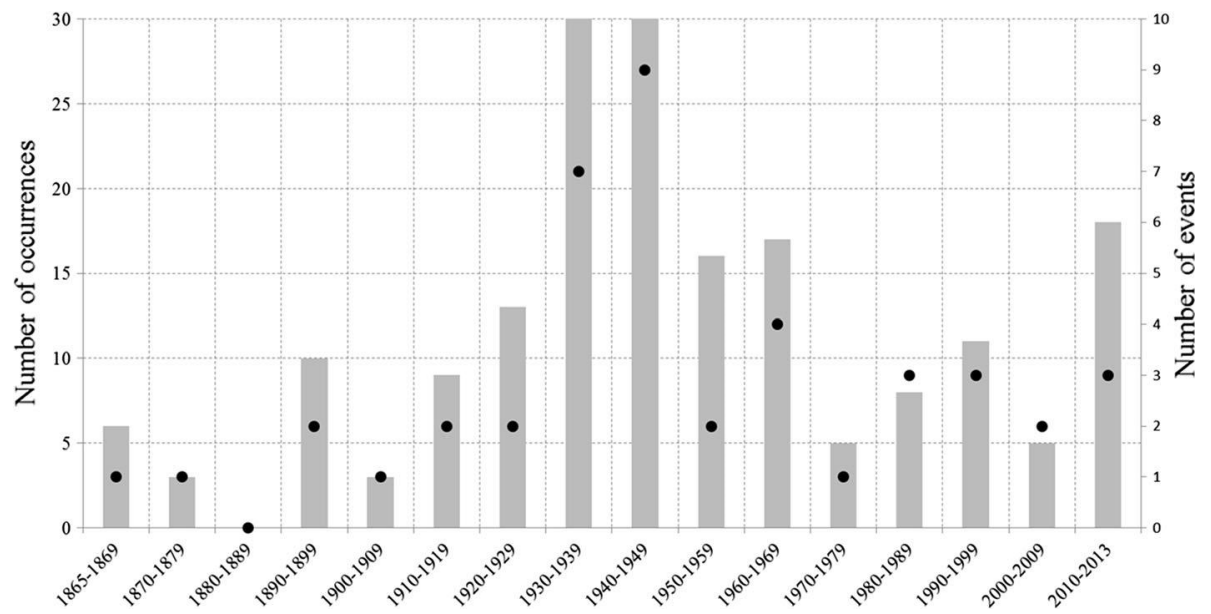

Fig. 2 Temporal distribution of decadal flood occurrences and events between 1865 and 2013. The circles represent the number of events for each period Source: Information in Rilo et al. (2015)

Different triggering factors contribute to flood occurrences along the Tagus estuarine margins. In the narrow upstream sector of the estuary, the river flow can have an important effect on water elevations. Elsewhere, the estuary cross-sectional area increases significantly and the water elevations are dominated by tides and storm surges (Vargas et al. 2008; Guerreiro et al. 2015).

In adjacent urban areas, high levels of estuarine waters can affect the drainage capacity of sewer systems, particularly during episodes of intense and concentrated in time rainfall (David et al. 2015). The past flood events are associated with multiple causes in the historical sources: periods of intense rainfall (95\% of total events), high fluvial discharge $(80 \%)$, deficient urban drainage (70\%), severe wave conditions (45\%), low atmospheric pressure events $(41 \%)$ and high tidal levels $(34 \%)$. The results based on historical information must be carefully assessed, as mentioned in previous studies (Barriendos et al. 2006; Santos et al. 2014), taking into account the reliability of the information sources (depending on the type of sources, variations of journalistic criteria through time) and of the database itself (depending on the inclusion criteria, availability of sources and temporal period covered by the database).

Due to their wide spatial effects and associated impacts, two historical flood events in Tagus estuary emerge from the available information previous described (Table 1): 15 February 1941 and 27 February 2010. The former is mentioned in the literature as the biggest catastrophe that occurred in the Iberian Peninsula in the last 200 years, causing high human casualties, extensive infrastructural damages and services disruption along the Portuguese coast (Muir-Wood 2011; Freitas and Dias 2013). Strong wave action driven by south-westerly winds combined with a major storm surge caused severe damages in houses and infrastructures along the Tagus estuarine margins between the estuary mouth and Vila Franca de Xira and the sinking of 150 boats close to Lisbon (Muir-Wood 2011). The resulting human losses registered include 28 casualties, 14 wounded, 125 evacuees and 3 displaced (Freire et al. 2015). The February 2010 flooding episode was associated with the Xynthia storm whose tragic effects in the western coast of France are well documented (Andre' et al. 2013). In the Tagus estuary, this storm, which followed a similar trajectory as the one that occurred in 1941 (Breilh et al. 2014), affected both margins between Oeiras 
Table 1 Potential forcing factors of maximum water levels (see Fig. 1 for locations)

\begin{tabular}{lllll}
\hline Event & $\begin{array}{l}\text { Tidal } \\
\text { range } \\
(\mathrm{m})^{\mathrm{a}}\end{array}$ & $\begin{array}{l}\text { Min. } \\
\text { atmospheric } \\
\text { pressure }(\mathrm{hPa})\end{array}$ & $\begin{array}{l}\text { Inverted } \\
\text { barometer } \\
\text { effect }(\mathrm{m})^{\mathrm{d}}\end{array}$ & $\begin{array}{l}\text { Maximum } \\
\text { surge level } \\
(\mathrm{m})^{\mathrm{e}}\end{array}$
\end{tabular}

and Vila Franca de Xira. Although without human losses, considerable damages in infrastructures were recorded at the estuarine waterfront including the Port of Lisbon facilities, located in the northern margin. One of the areas most affected by this event was the Seixal waterfront (Fig. 1) where the flood impacted private homes and commercial buildings and disrupted the traffic on public roads in the historical district. The analysis of the potential water levels forcings in the estuary (tide, atmospheric pressure, wind and Tagus river discharge) during the two historical events shows that flooding levels in both events are associated with the combination of spring tide, storm surge conditions (above $0.60 \mathrm{~m}$ ) and very strong local winds (maximum intensity in Lisbon of about $130 \mathrm{~km} / \mathrm{h}$ in 1941 and wind gusts over $100 \mathrm{~km} / \mathrm{h}$ in 2010) (Table 1).

\subsection{Extreme water levels}

Water levels in estuaries depend on several meteorological and astronomic forcing agents: tides, wind, atmospheric pressure, river flow and waves. However, the relative importance of the different forcing agents varies widely across and within estuaries. In the particular case of the Tagus estuary, the variability of the water level is mostly due to tides. Tidal ranges at the coast (Cascais) vary between 0.55 and $3.86 \mathrm{~m}$ (Guerreiro et al. 2015). Inside the estuary, these tidal ranges are further amplified by resonance, which selectively amplifies semi-diurnal constituents (Fortunato et al. 1999). Storm surges can also contribute significantly to the water level. Andrade et al. (2006) estimated storm surges of 46$58 \mathrm{~cm}$ at Cascais, for return periods of 5 and 100 years, respectively. In contrast, the effect of river flow on water levels is limited to the upper reaches of the estuary, about $40 \mathrm{~km}$ upstream of the mouth (Vargas et al. 2008).

The water levels in the estuary, for a return period of 100 years and present mean sea level (MSL), vary from about $4.5 \mathrm{~m}$ (CD chart datum: $2.08 \mathrm{~m}$ below MSL) at the estuary mouth to $5.1 \mathrm{~m}(\mathrm{CD})$ at its head (Fig. 3). Several marginal areas are inundated, including the Seixal area and its surroundings. 


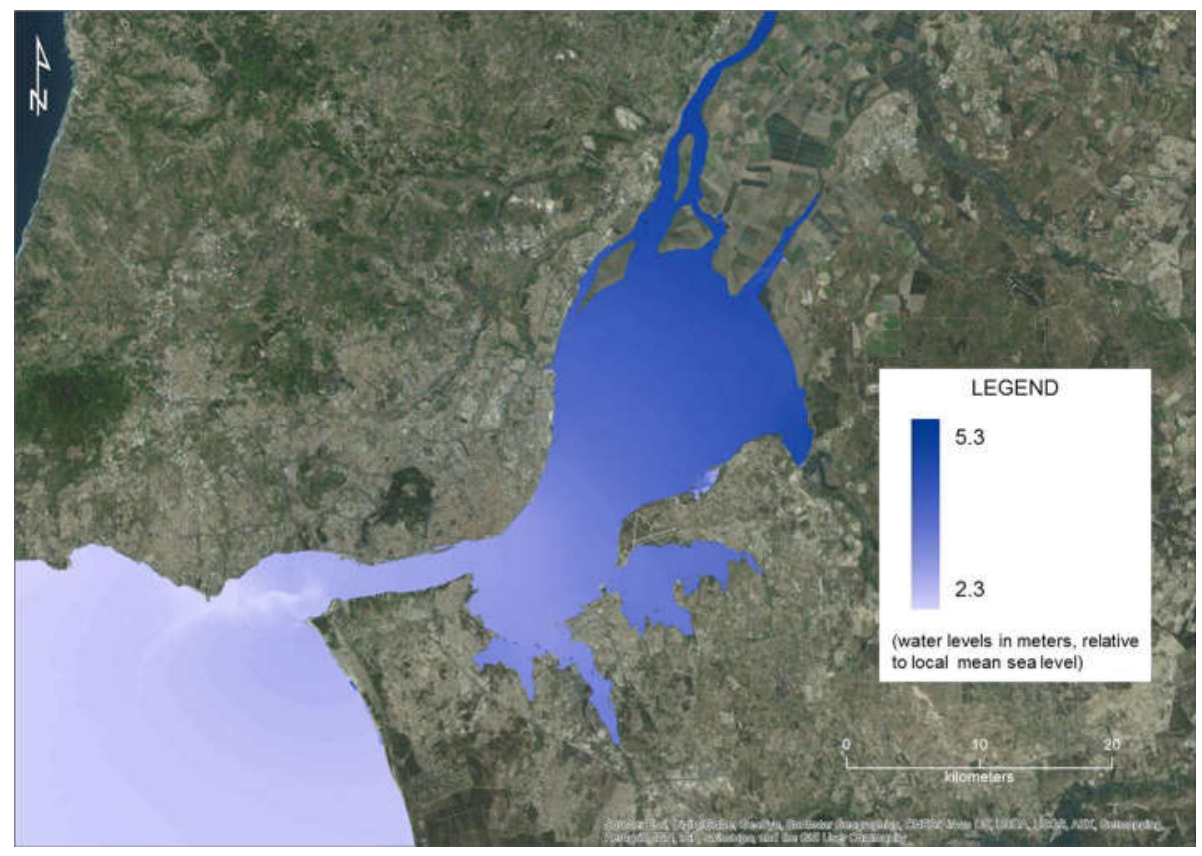

Fig. 3 Extreme water levels in the Tagus estuary for a return period of 100 years. This map was generated by forcing a circulation model of the estuary with a time series of elevations produced by a statistical analysis of tide gauge data from Cascais. The method is described in Fortunato et al. (2013) and its application to the Tagus estuary in Guerreiro et al. (2015). The application and validation of the circulation model is presented in Fortunato et al. (2015). See Sect. 3.2 for further details

\subsection{Territorial vulnerability}

The knowledge of the vulnerability of a given territory has several applications in risk management. It is a concept closely related to resilience, quantifying a community's capacity to adapt and recover from disasters (Cutter et al. 2008; Bergstrand et al. 2015). Applications can be identified according to the selected geographical scale of analysis: nationwide assessments produce knowledge from a global risk governance perspective (Angeon and Bates 2015), while local applications are useful, for example, in emergency and spatial planning at the municipal level (Guillard-Gonc, alves et al. 2014; Perrow 2006, 2007).

In the present study, the assessment of territorial vulnerability contributes to a wider framing of the Tagus estuary regarding its socio-economic, demographic and urban characteristics and dynamics. Additionally, such assessment contributes to the identifica-tion of vulnerability drivers and a detailed knowledge on the location of the most vul-nerable risk groups (Cutter et al. 2003; IPCC 2014). A territorial vulnerability assessment methodology was applied to the Tagus estuary area (Tavares et al. 2015) over a set of 1147 statistical blocks located along the estuarine margins, in order to consider both directly and indirectly affected areas. The assessment identified old buildings and neighbourhoods, aged population, unemployment, caregiving responsibilities, educational level, commu-tation dependency and urban density as the main vulnerability drivers, exemplified by the areas numbered 2, 4 and 5 in Fig. 4 . In contrast, in the areas numbered 1, 3 and 6 , statistical 


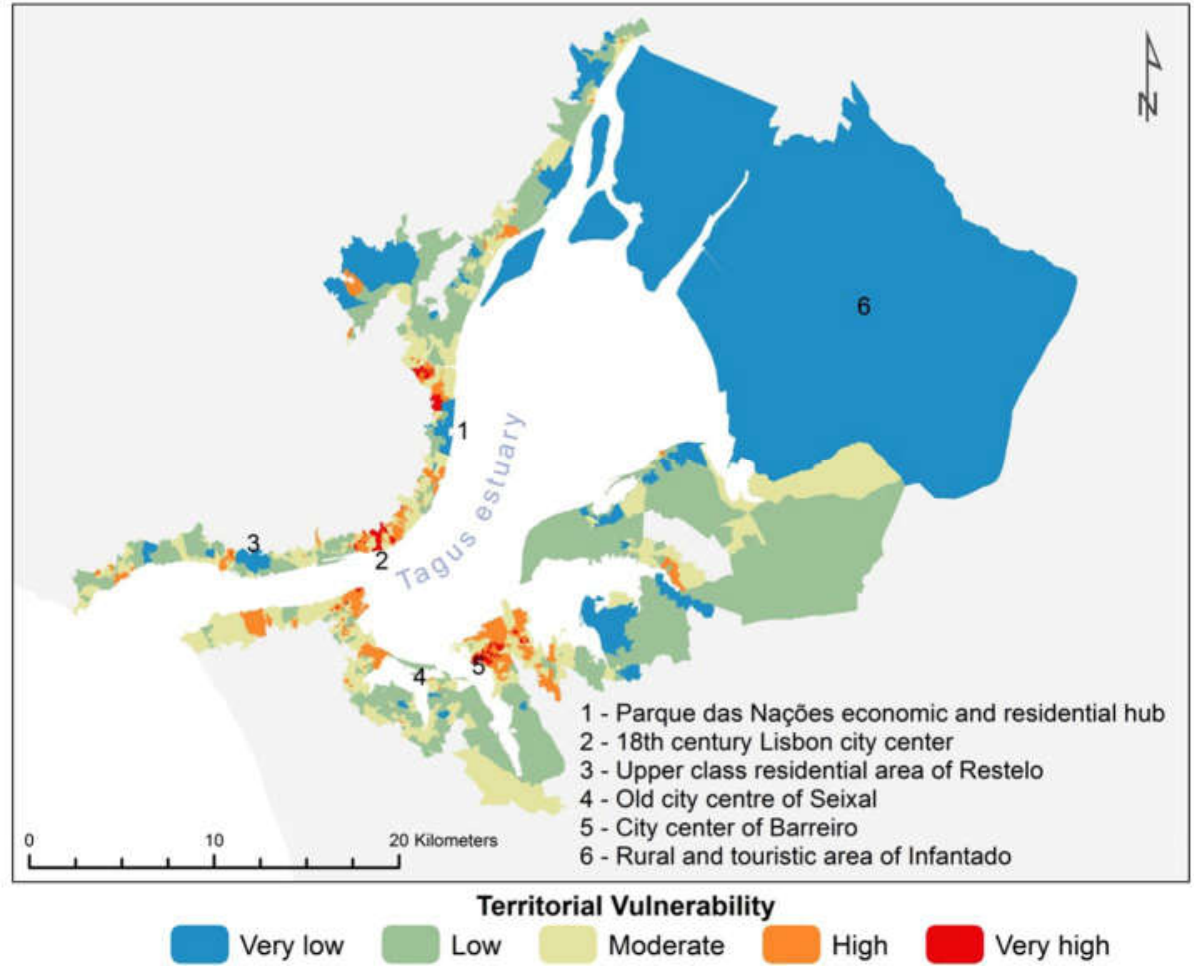

Fig. 4 Territorial vulnerability in the Tagus estuary

blocks characterized by high percentage of individuals and families with high educational level and economic status and low rate of unemployment present a low social vulnerability.

\subsection{Seixal waterfront characterization}

The waterfront of the Seixal Municipality is located in the southern margin of the Tagus estuary (Fig. 5) and is the local study area of this work. The downscale of analysis from the estuary level to this municipality requires specific strategies of flood risk management and, therefore, specific methods of risk assessment.

The waterfront of the Seixal Municipality is comprised of three parishes - parish of Seixal, Arrentela and Aldeia de Paio Pires, parish of Amora and parish of Corroios - which are the local administrative and political organizational level. They all present a very similar number of residents (44 920, 48629 and 47661 , respectively). Nevertheless, the area closer to the waterfront - a buffer with a length of $1000 \mathrm{~m}$ considered in the territorial vulnerability assessment-registers, in those three parishes, a total of 92,004 inhabitants, representing 65.2 $\%$ of the total resident population. Hence, a significant proportion of each parish's population resides near the shoreline. The waterfront has different typologies of urban occupation, from a consolidated old city centre to more dispersed urban areas that grew over time. The land-use in non-urban areas is composed of natural and wetland areas, aquaculture, active and inactive naval shipyards, abandoned industrial areas and 
(a)

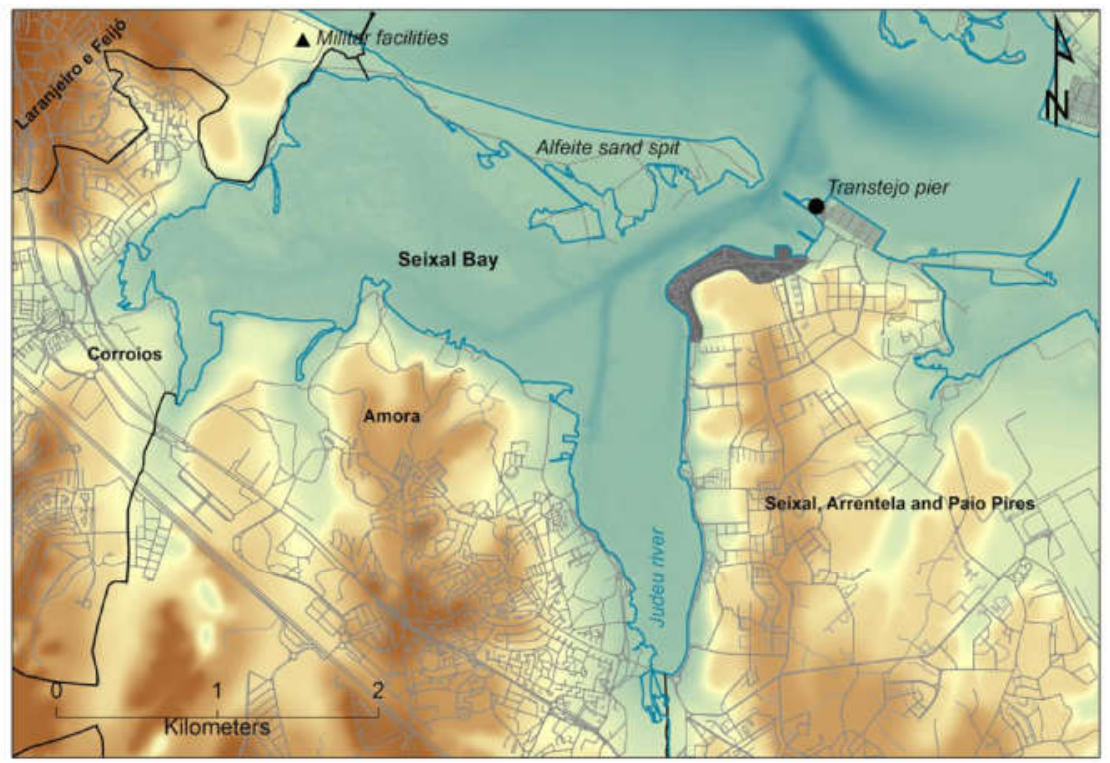

Legend

(b)

roads infrastructure $\quad$ Seixal old city center —_ Highest astronomical tide line
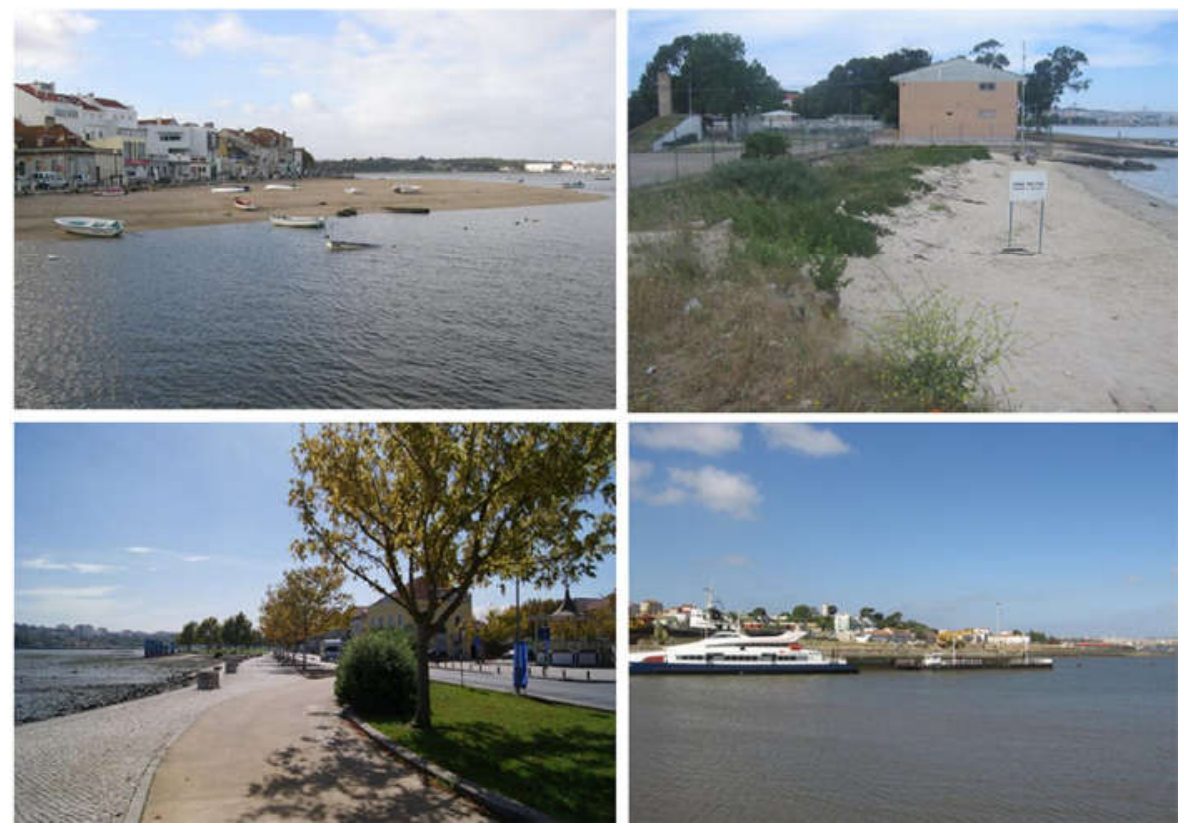

Fig. 5 a Seixal waterfront showing block statistical-level division, b Four different aspects of Seixal waterfront territory. Digital terrain model based on: topographic information from the Military Chart (1/25000 scale) from the Centro de Informac,a ̃o Geoespacial do Exe'rcito (CIGeoE), topographic data from the Agencia Portuguesa do Ambiente (APA) and bathymetric data provided by the Seixal Municipality 
recreational areas. The municipality's most relevant critical infrastructure is the road and fluvial interface which provides transportation between the two margins of the estuary.

In terms of hydrological features, the Seixal waterfront is configured by a small bay (about 480 ha in area) in which a tidal channel system nourishes silty-mud flats and salt marshes (Fig. 5). The bay is sheltered from the direct influence of the estuary by a $2.3-\mathrm{km}-$ long sand spit with an active beach anchored in the northern side (Alfeite beach), one of the longest beaches in the estuary (Freire et al. 2013). The channel of the Judeu river connects the interior of the bay with the estuary. Due to its natural resources and sheltered condi-tions, this area has long attracted human activities mainly associated with fishery and shipbuilding, hosting also harbour and military facilities. These natural characteristics make the Seixal waterfront widely used by the local population for recreational activities, such as nautical activities and bird watching, justifying a municipal investment in marginal facilities for jogging and cycling, along with an eco-museum at an old water mill.

\section{Methodological approach}

\subsection{General approach}

Adequate flood risk management measures in transitional systems should be sustained by validated risk assessment methodologies that integrate the diversity of hazard sources. Herein, a risk management strategy is proposed that aims at providing a scientific and information-based support to enhanced flood risk management measures. This risk management approach is schematically presented in Fig. 6 and is split into two major sections: risk management and decision-making.

\subsection{Risk assessment}

Information on past flood events contributes to improving the knowledge about flood drivers, flood characteristics and associated impacts. Historical flood records for the Seixal

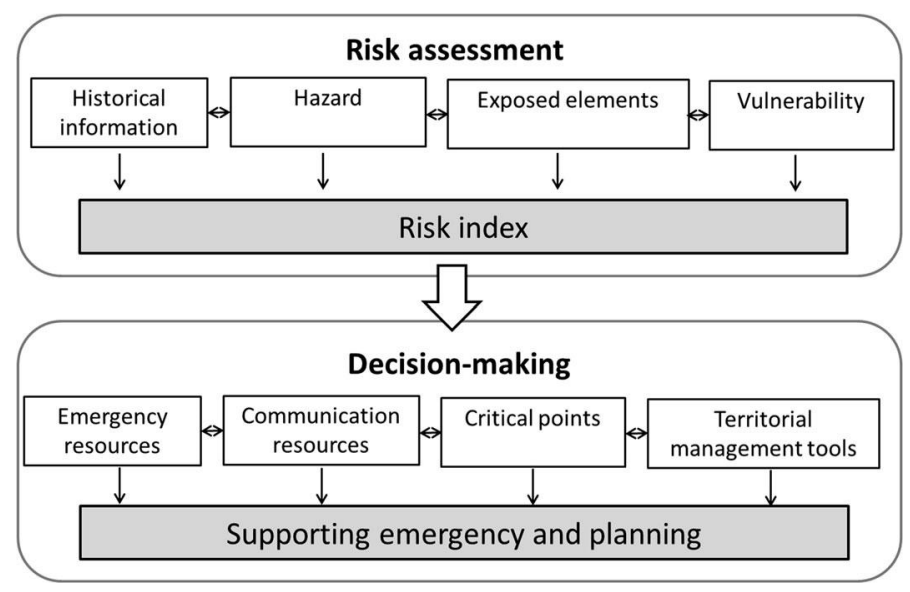

Fig. 6 Risk management approach scheme followed in the present study 
Municipality were assessed through the compilation of two local databases of flood occurrences maintained by the local emergency authorities: the Seixal fire department and the Seixal Municipal Service for Civil Protection (SMPCS). Those two databases were analysed and compiled into a single local database (L_DB) structure to allow the integration of different types of data. Since the objective was to capture the estuarine influence on floods, only the occurrences related to flood events of natural origin and geographically located below $20 \mathrm{~m}$ (MSL) were considered. The L_DB is structured in four groups of information: basic data regarding date and location, flood impacts (e.g. casualties, damages), flood characteristics (e.g. flood extension, depth) and flood-triggering factors (e.g. rainfall, fluvial discharge, tides).

In the scope of the characterization of past events, the maximum extension of flooded area in Seixal old city centre in 2010 was reconstructed using a RTK-DGPS with the support of the Seixal Municipality services. The results were further complemented with photographs and other records acquired during the event. To complement the historical information, the flood extension and impacts and the water levels in the estuary were also acquired in situ during particular oceanographic and meteorological conditions that occurred in 2014 and 2015. All the acquired data provided crucial information for understanding the flooding process and hazard assessment validation.

Considering that the flood hazard at a given location depends on the hydrodynamic conditions, its assessment was based on the hazard index defined by DEFRA (2006):

$$
\text { Ih } 1 / 4 \text { H ठ U p 0:5p }
$$

where $\mathrm{H}$ (in $\mathrm{m}$ ) is the total water depth and $\mathrm{U}$ (in $\mathrm{m} / \mathrm{s}$ ) is the depth-averaged velocity. Four classes of increasing hazard are defined based on the value of $I_{h}$ (Table 2).

The spatial and temporal evolution of the total water depth and the depth-averaged velocity was determined using the circulation model SCHISM (Zhang et al. 2016). Derived from SELFE (Zhang and Baptista 2008), SCHISM is an open-source community-supported modelling system based on unstructured grids, designed for the seamless simulation of 3D baroclinic circulation across lake-river-estuary-shelf-ocean scales. Details on the appli-cation and validation of SCHISM in the Tagus estuary are provided in Fortunato et al. (2015). To construct the hazard maps, the model is forced at its ocean boundary by time series of elevations representative of conditions for selected return periods. These time series are generated through a statistical analysis of tide gauge data at the Cascais tide gauge, following the procedure described in Fortunato et al. (2013) and Guerreiro et al. (2015). The horizontal resolution of the model in the estuarine margins is of the order of a few tens of metres. While this resolution can be considered very fine, given the extent of the model, it is not sufficient to represent the building and other obstacles to the flow. The resistance caused by these subgridscale features on the flow is thus represented with added friction, based on the land cover. While this approach is adequate to determine the free surface elevation, it leads to the underprediction of the maximum velocities (Le Roy et al.

Table 2 Classes of the hazard index and description based on DEFRA (2006)

\begin{tabular}{lllll}
\hline Hazard index & $\mathrm{I}_{\mathrm{h}}$ B 0.75 & $0.75 \backslash \mathrm{I}_{\mathrm{h}}$ B 1.25 & $1.25 \backslash \mathrm{I}_{\mathrm{h}} \mathrm{B} 2.5$ & $\mathrm{I}_{\mathrm{h}}[2.5$ \\
\hline $\begin{array}{llll}\text { Degree of hazard } \\
\text { Description }\end{array}$ & $\begin{array}{l}\text { 1-low } \\
\text { Caution }\end{array}$ & $\begin{array}{l}2 \text {-moderate } \\
\text { Dangerous for some }\end{array}$ & $\begin{array}{l}\text { 3-significant } \\
\text { Dangerous for most people }\end{array}$ & Dangerous for all \\
\hline
\end{tabular}


2015). Therefore, the hazard also tends to be underpredicted in urban areas. The following three scenarios were considered: 100 -year probability with a 1-m sea level rise (SLR), and 20- and 100-year probability without SLR.

The identification of exposed elements was based on geographic data obtained from various sources: the National Authority for Civil Protection (ANPC), the Municipal Service for Civil Protection (SMPCS) and those produced in previous projects made publicly available by Central Administration entities. The typology of exposed elements includes:

- Building implantation, road network and business/commercial points of interest;

- Critical infrastructures: civil protection, elderly population, childhood and education, leisure and sport, health, transportation, industrial areas, water supply and treatment;

- Cultural and architectural heritage;

- Land-use and land value: MorFeed Project land-use data (Rilo et al. 2013), Corine Land Cover 2012 data, property tax coefficient mapping;

- Environmental assets: stream network, notable trees, Urban Waste Water Directive sensitive zones, coastal ecosystems (MorFeed Project data).

The spatial representation of these elements was overlaid with the considered present and future estuarine flooding scenarios.

The vulnerability assessment considered the following typology of exposed elements: road network; buildings and environmental critical infrastructures; mobility (assessed through the presence of ATM machines, bus stops and transport hubs/interfaces); people's presence (assessed through the counting of circulating vehicles and parked vehicles through satellite imagery of the years 2007, 2011 and 2012). Following the assessment approach proposed by the Department for Environment, Food \& Rural Affairs (DEFRA 2006), these elements define the area vulnerability $\left(A_{V}\right)$.

Using the same approach of DEFRA, a value of people vulnerability $\left(\mathrm{P}_{\mathrm{V}}\right)$ is taken from the assessment conducted at the estuary level, where the scores resulting from the principal component analysis (PCA) at each statistical block are used.

Table 3 presents the form in which input data are processed in order to calculate $A_{V}$ and $P_{V}$. The product of $A_{V}$ and $P_{V}$ is the vulnerability index $\left(I_{V}\right)$. $I_{V}$ expresses therefore several dimensions of the vulnerability: those arising from the individual social characteristics, and those imposed by the territorial context both in terms of resident and transient population and in terms of activities. Rows from (a) to (g) and $\mathrm{P}_{\mathrm{V}}$ identify raw input data. The mobility parameter $\left(\mathrm{M}_{\mathrm{p}}\right)$ is the simple average of $(\mathrm{c})$ and $(\mathrm{d})$. The concentration areas parameter $(\mathrm{Cap})$ is the simple average of (e) and (f). The range of values in the different parameters is highly variable, in accordance with the distinct nature and measure units in which they are expressed. For this reason, a linear transformation is performed using the minimum and maximum values in the parameters whose range is not initially between the interval $[0,1]$, in order to allow a direct calculus of $A_{V}$ (Table 3 ).

Besides their representation as geographical entities (points, lines and areas), a vulnerability index $\left(\mathrm{I}_{\mathrm{V}}\right)$ is evaluated by relating topologically these elements with the flood hazard index $\left(\mathrm{I}_{\mathrm{h}}\right)$, which is expressed using a triangular network. This approach facilitates the calculus of the risk index because each triangle is assigned a hazard value as described above.

The risk index $\left(\mathrm{I}_{\mathrm{r}}\right)$ is therefore the product of $\mathrm{I}_{\mathrm{h}}$ and $\mathrm{I}_{\mathrm{V}}$ in each triangle. 
Table 3 Input data and processing for the evaluation of the vulnerability index

\begin{tabular}{|c|c|c|}
\hline \multicolumn{3}{|l|}{ Input data } \\
\hline Variables & Units & Scores \\
\hline Road network density (a) & \multicolumn{2}{|l|}{$\mathrm{km} / \mathrm{km}^{2}$} \\
\hline Proportion of built areas (b) & \multicolumn{2}{|l|}{$\%$} \\
\hline Vehicles' location (c) & \multicolumn{2}{|c|}{ Average of the number of vehicles in 3 different time frames } \\
\hline $\begin{array}{l}\text { Bus stop coverage (d) } \\
\text { ATM and bank coverage (e) }\end{array}$ & \multirow[t]{3}{*}{ Dimensionless } & \multirow[t]{3}{*}{$\begin{array}{l}1 \text { - exact location, } 0.5 \text {-adjacent location, } 0 \text {-other } \\
\text { locations }^{\mathrm{a}}\end{array}$} \\
\hline Fluvial station (f) & & \\
\hline $\begin{array}{l}\text { Environmental infrastructures } \\
(\mathrm{g})\end{array}$ & & \\
\hline People vulnerability $\left(\mathrm{P}_{\mathrm{v}}\right)$ & Dimensionless & $\begin{array}{l}\text { Score of the territorial vulnerability assessment } \\
\text { (between } 0 \text { and } 1 \text { ) }\end{array}$ \\
\hline \multicolumn{3}{|l|}{ Intermediate parameters } \\
\hline Mobility parameter $\left(\mathrm{M}_{\mathrm{p}}\right)$ & \multicolumn{2}{|l|}{$\mathrm{M}_{\mathrm{p}}=[(\mathrm{c}) ?(\mathrm{~d})] / 2$} \\
\hline $\begin{array}{l}\text { Concentration areas' parameter } \\
\left(\mathrm{Ca}_{\mathrm{p}}\right)\end{array}$ & \multicolumn{2}{|c|}{$\mathrm{Ca}_{\mathrm{p}}=[(\mathrm{e}) ?(\mathrm{f})] / 2$} \\
\hline Area vulnerability $\left(A_{V}\right)$ & \multicolumn{2}{|c|}{$\mathrm{A}_{\mathrm{V}}=\left[(\mathrm{a}) ?(\mathrm{~b}) ?\left(\mathrm{M}_{\mathrm{p}}\right) ?(\mathrm{Ca}) ?(\mathrm{~g})\right] / 5$} \\
\hline Vulnerability index $\left(\mathrm{I}_{\mathrm{V}}\right)$ & \multicolumn{2}{|l|}{$\mathrm{I}_{\mathrm{y}}=\mathrm{A}_{\mathrm{y}} \mathrm{P}_{\mathrm{y}}$} \\
\hline
\end{tabular}

\subsection{Decision-making supporting tools}

The developed approach focuses on two different dimensions of the decision-making support: (a) emergency planning and response to floods, based on a real-time forecast and early warning system communication framework; (b) territorial planning instruments based on potential flooding areas for different climate scenarios.

Two different emergency resources are available to support the decision-making strategy: the real-time data resources (Table 4) that provide the background data to the forecast and early warning system, and the emergency resources from the national and local civil protection services (Table 5).

\subsubsection{Communication resources}

An innovative real-time information system for enhanced support to flood risk emergency was developed to provide a gateway to all project data, from both emergency and risk analysis products. This information system was based on a customized deployment of the WIFF-Water Information Forecast Framework (Oliveira et al. 2014; Fortunato et al. 2015) - to address the specific requirements of flood risk management. The platform addresses several user requirements such as (1) fast, online access to relevant georeferenced information from wireless sensors, high-resolution forecasts and comprehensive risk analysis; and (2) the ability to adapt automatically and transparently to any device with data connection. Given its specific purpose, both data protection and tailored-to-purpose products are planned for through user-specific access roles. 
Table 4 Real-time information resources

\begin{tabular}{|c|c|c|}
\hline Resources & Provider & Description \\
\hline \multicolumn{3}{|l|}{ Regional } \\
\hline $\begin{array}{l}\text { Atmospheric } \\
\text { forecasting } \\
\text { tools }\end{array}$ & NOAA (www.ncdc.noaa.gov) & $\begin{array}{l}\text { Global forecast system wind and } \\
\text { atmospheric pressure predictions }\end{array}$ \\
\hline $\begin{array}{l}\text { Oceanic } \\
\quad \text { forecasting } \\
\text { tools }\end{array}$ & $\begin{array}{l}\text { LNEC_-National Laboratory for Civil } \\
\text { Engineering (http://ariel.lnec.pt/) }\end{array}$ & Wave and sea level predictions \\
\hline $\begin{array}{l}\text { In situ } \\
\text { monitoring } \\
\text { sensors }\end{array}$ & $\begin{array}{l}\text { IH-Hydrographic Institute through } \\
\text { EMODnet (www.emodnet.eu/) }\end{array}$ & $\begin{array}{l}\text { Sea level and mean wave parameters } \\
\text { data }\end{array}$ \\
\hline \multicolumn{3}{|l|}{ Local } \\
\hline $\begin{array}{l}\text { Atmospheric } \\
\text { forecasting } \\
\text { tools }\end{array}$ & Windguru (www.windguru.cz/) & $\begin{array}{l}\text { Wind and atmospheric pressure } \\
\text { predictions }\end{array}$ \\
\hline $\begin{array}{l}\text { In situ } \\
\quad \text { monitoring } \\
\text { sensors }\end{array}$ & $\begin{array}{l}\text { APA_Portuguese Environment Agency } \\
\text { (snirh.pt) }\end{array}$ & River discharge data \\
\hline $\begin{array}{l}\text { In situ } \\
\text { monitoring } \\
\text { sensors }\end{array}$ & $\begin{array}{l}\text { DGT_-Directorate General for Territory } \\
\text { (www.dgterritorio.pt) }\end{array}$ & Sea level data \\
\hline $\begin{array}{l}\text { In situ } \\
\text { monitoring } \\
\text { sensors }\end{array}$ & $\begin{array}{l}\text { APL_-The Port of Lisbon (www. } \\
\text { portodelisboa.pt) }\end{array}$ & Sea level data \\
\hline
\end{tabular}

\subsubsection{Critical points}

The flood early warning system was implemented for selected critical points considering the risk assessment results and applying the following criteria:

- The early warning system should serve the areas directly affected by flooding classified with high and very high risk in the $\mathrm{I}_{\mathrm{r}}$;

- The early warning system should serve the areas directly affected by flooding classified with very low, low and moderate risk in the $\mathrm{I}_{\mathrm{r}}$, as long as they provide road or fluvial connectivity to areas - inside or outside the hazard areas - which would be significantly and indirectly affected by the disruption of such functions.

Four flooding warning levels were defined based on the forecast water height $(\mathrm{H})$ (negative values correspond to situations in which the water surface at a nearby point is below the topographic height of the critical point) and the potential impacts.

- Level 1 (green) - $\mathrm{H} \backslash-0.20 \mathrm{~m}$ : no warning, corresponds to the normal situation.

- Level 2 (yellow)-B-0.20 m H $\backslash 0.20 \mathrm{~m}$ : possible low flooding; the low-lying areas next to the water front may be flooded. Roads may be closed, and bicycle and pedestrian paths as well as some backyards of buildings may be affected.

- Level 3 (orange) - B $0.20 \mathrm{~m} \mathrm{H} \backslash 0.50 \mathrm{~m}$ : low to moderate flooding; in addition to the above, the flooded area is more substantial. Some buildings below the floor level may be affected.

- Level 4 (red) - H C $0.50 \mathrm{~m}$ : high flooding; in addition to the above, extensive areas are flooded. Many buildings may be affected below the floor level and some above the floor level. 
Table 5 Civil protection resources

\begin{tabular}{|c|c|c|}
\hline Provider & Resources & Description \\
\hline \multicolumn{3}{|l|}{ National level } \\
\hline \multirow[t]{5}{*}{ ANPC } & \multirow[t]{3}{*}{ Human } & $\begin{array}{l}\text { The national authority of civil protection (Portuguese acronym } \\
\text { ANPC) has the role of planning, coordinating and implementing } \\
\text { the civil protection policy. It is also responsible for the civil } \\
\text { protection resources, emergency planning and firefighters and } \\
\text { maintains a central operational service }\end{array}$ \\
\hline & & $\begin{array}{l}\text { The firefighters force (in Portuguese Forc, a Especial de Bombeiros- } \\
\text { FEB) is the branch of ANPC for disaster relief during } \\
\text { emergencies, including floods and other adverse weather } \\
\text { conditions hazards }\end{array}$ \\
\hline & & $\begin{array}{l}\text { In terms of civil protection human resources, FEB effective scales } \\
\text { to } 280 \text { persons adding other security forces, armed Forces, } \\
\text { maritime and aeronautical authorities, National Institute for } \\
\text { Medical Emergency and other health services }\end{array}$ \\
\hline & \multirow[t]{2}{*}{ Material } & $\begin{array}{l}\text { The FEB has currently } 57 \text { operational vehicles and } 9 \text { lighting } \\
\text { balloons, } 2 \text { rescue vessels, } 8 \text { diving equipment, } 10 \text { aquatic rescue } \\
\text { equipment, } 12 \text { rescue and extrication equipment, } 1 \text { rescue } \\
\text { equipment in wide angle, } 2 \text { high-capacity generators, } 16 \text { medium- } \\
\text { capacity generators, and } 7 \text { large inflatable tents }\end{array}$ \\
\hline & & $\begin{array}{l}\text { An integrated emergency and security communication network } \\
\text { (SIRESP) ensures the communications needs of the emergency } \\
\text { forces and security services, allowing intercommunication and } \\
\text { interoperability between those forces and services }\end{array}$ \\
\hline \multicolumn{3}{|l|}{ Municipal level } \\
\hline \multirow[t]{2}{*}{ SMPCS } & Human & $\begin{array}{l}1 \text { Tactical team ( } 2 \text { members), } 1 \text { operational team ( } 3 \text { members) } \\
\text { municipality backup human resources }(1.600)\end{array}$ \\
\hline & Material & $\begin{array}{l}2 \text { Tactical vehicles, specific emergency radio frequency and } 20 \\
\text { radio devices, municipality backup resources ( } 235 \text { vehicles and } \\
\text { construction equipment, } 1 \text { boat, about } 1.000 \text { warning and traffic } \\
\text { signs) }\end{array}$ \\
\hline \multirow[t]{2}{*}{ Fire brigades } & Human & $\begin{array}{l}280 \text { (firefighters and rescue team members), } 3 \text { rescue teams, } 1 \\
\text { diving brigade }\end{array}$ \\
\hline & Material & $\begin{array}{l}54 \text { vehicles, } 3 \text { boats, } 21 \text { ambulances, } 18 \text { rescue vehicles, } 3 \\
\text { communication and command vehicles, } 12 \text { other vehicles for } \\
\text { transportation and logistics }\end{array}$ \\
\hline
\end{tabular}

\subsubsection{Territorial management tools}

In recent decades, municipal land-use management and planning has been vastly improved through the implementation of mandatory municipal land-use plans (PDMs) and the introduction therein of several national, regional, and local theme maps and strategies. In their latest revision, they are now required to include risk maps, which highlight the territorial vulnerability associated with natural and technological hazards. Flood-prone areas are equally required to be transposed into zoning and building restrictions as part of the National Ecological Reserve. While this has been mandatory since 1990, the technical requirements and methods have been recently improved to reflect the transposition of the Floods Directive (Directive 2007/60/EC) into national law. 
These changes, implemented ultimately at the municipal level, often derive from indications emanating from regional plans or national strategies. The Regional Land-Use Plan (PROT-AML) and the Estuary Management Plan (POET) are of particular interest to the Seixal waterfront and to the estuary as a whole. Both plans are pending final approval, but some of the measures therein are already being recommended by the Regional Coordinating Commission (CCDR) and the Portuguese Environmental Agency (APA), both central government agencies. Other sectoral plans, such as the Natura 2000 Plan, the Tagus River Basin Management Plan, or the Natural Reserve Management Plan, require incorporation into municipal planning, but their influence over local decision-making is less pronounced in the case of Seixal. Municipal emergency planning deserves a separate document (Seixal's latest Emergency Plan was approved in 2014 and is targeted mostly at emergency response and coordination among civil protection agents).

\section{Risk assessment}

\subsection{Historical flood records}

Historical flood records in the Seixal waterfront compiled in the L_DB comprise 48 occurrences between 2002 and 2013. From these occurrences, $40 \%$ had physical impacts, such as damages in basements, commercial stores and private houses, and $42 \%$ registered societal impacts related to traffic disruption due to flooding forcing the public authorities' involvement (Table 6).

The occurrences with the most relevant impacts occurred on 27 February and 2 March 2 2010, during which the Seixal old city centre was partially inundated (Fig. 7). The first occurrence is associated with the Xynthia storm already described in Sect. 2 and was driven by the combination of high tidal level $(4.2 \mathrm{~m}$ above $\mathrm{CD}$ ), storm surge (about $0.6 \mathrm{~m}$ ) and strong wind (maximum intensity of about $100 \mathrm{~km} / \mathrm{h}$ ) directed towards the cost. On $2 \mathrm{March}$, the flood episode is also related to high tidal level, in this case higher than before ( $4.3 \mathrm{~m}$ above CD), and surge conditions relevant but smaller than in the previous episode (about $0.4 \mathrm{~m}$ ). Regarding physical impacts, extensive damages in basements and road infrastructures were registered, adding to societal impacts resulting mainly from traffic and services disruption. The acquired in situ data, as a complement of the historical records, show that in the Seixal Municipality, two types of flooding events, based on their fre-quency and degree of impact, have to be considered in risk management: the high-impact low-frequency events, such as the one on 27 February, and more frequent flooding episodes with less severe consequences occurring during extreme high water levels, particularly forced by tide (equinoctial maximum levels) and atmospheric pressure. The latter result from the water inflow into the urban drainage system and its return by sinks that is

Table 6 Number of occurrences by type of impact in the Seixal waterfront area registered in the L_DB between 2002 and 2013

\begin{tabular}{ll}
\hline Type of impact & $\begin{array}{l}\text { Total number of } \\
\text { occurrences }\end{array}$ \\
\hline $\begin{array}{l}\text { Occurrences with institutional } \\
\text { involvement }\end{array}$ & 48 \\
Human losses & 0 \\
Flood damages & 19 \\
Traffic disruption & 20 \\
\hline
\end{tabular}



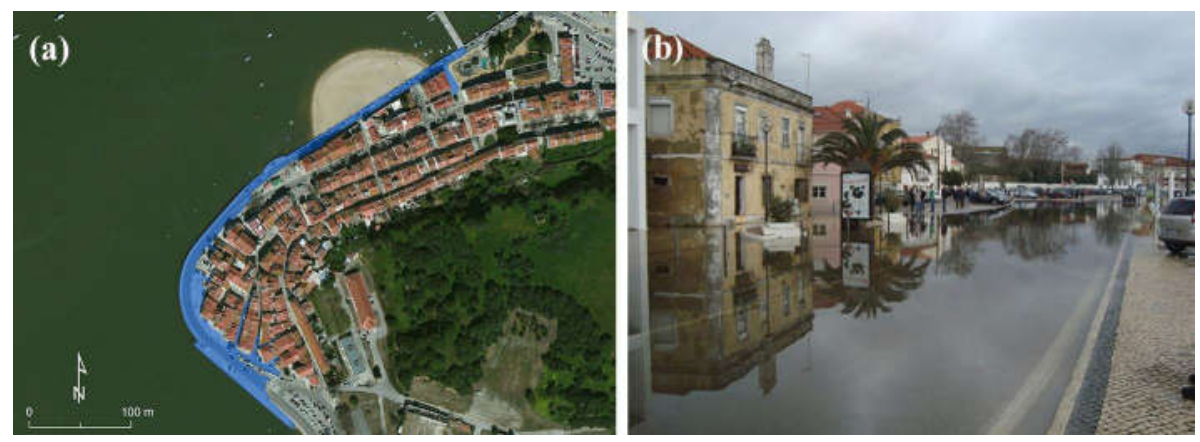

Fig. 7 February-March 2010 flooding events: a reconstruction of the flooding extension in the Seixal old city centre (image: ESRI Aerial Imagery); b aspect of the urban flooding area, 02 March 2010 (image source: Câmara Municipal do Seixal)

intensified during heavy rainfall episodes. The flooding promoted by direct overtopping of the margins is less frequent, but may occur due to the effect of wind waves during extreme high water levels. Depending on the flooding severity, no physical impacts are associated with the low-impact high-frequency events, but traffic and services disruption requires institutional involvement.

\subsection{Hazard assessment}

The Seixal Municipality waterfront is potentially affected by flooding in all the waterlevel scenarios with, as expected, higher expression when the sea level rise is considered (Fig. 8). Along the water adjacent fringe, persistent affected areas include the Seixal old city centre and Arrentela and Amora urban areas, road and fluvial interfaces, industrial zones (aquiculture farms, naval shipyards) and military facilities. Due to its low topography (average elevation of $1.93 \mathrm{~m}$ above MSL), the Alfeite sand spit shows the most extensive are affected.

The total potential flooded extent varies from 93 to 100 ha for the 20- and 100-year probability scenarios, respectively, increasing to 196 ha for the worst-case scenario (with sea level rise). Similar expression of the significant and extreme degrees of hazard (classes 3 and 4 ) is obtained for the 20- and 100-year scenarios (30 and 35\% of the total flooded area), extending to $77 \%$ when sea level rise is considered.

\subsection{Exposed elements and vulnerability assessment}

Following the findings of the territorial vulnerability assessment at the estuary level, the identification of exposed elements and assessment of vulnerability in the Seixal Municipality valued the local dynamics related to mobility and commutation, along with the exposed elements usually considered. Therefore, the exposed elements to estuarine flooding in the Seixal waterfront include residential buildings, road network, military, port and environmental infrastructures - such as water and sewage treatment facilities - and built, cultural and natural heritage such as tide mills, sand beaches and marshlands.

Table 7 summarizes the results of the vulnerability assessment, where the area covered by each input data and parameter of vulnerability, using natural neighbourhood 

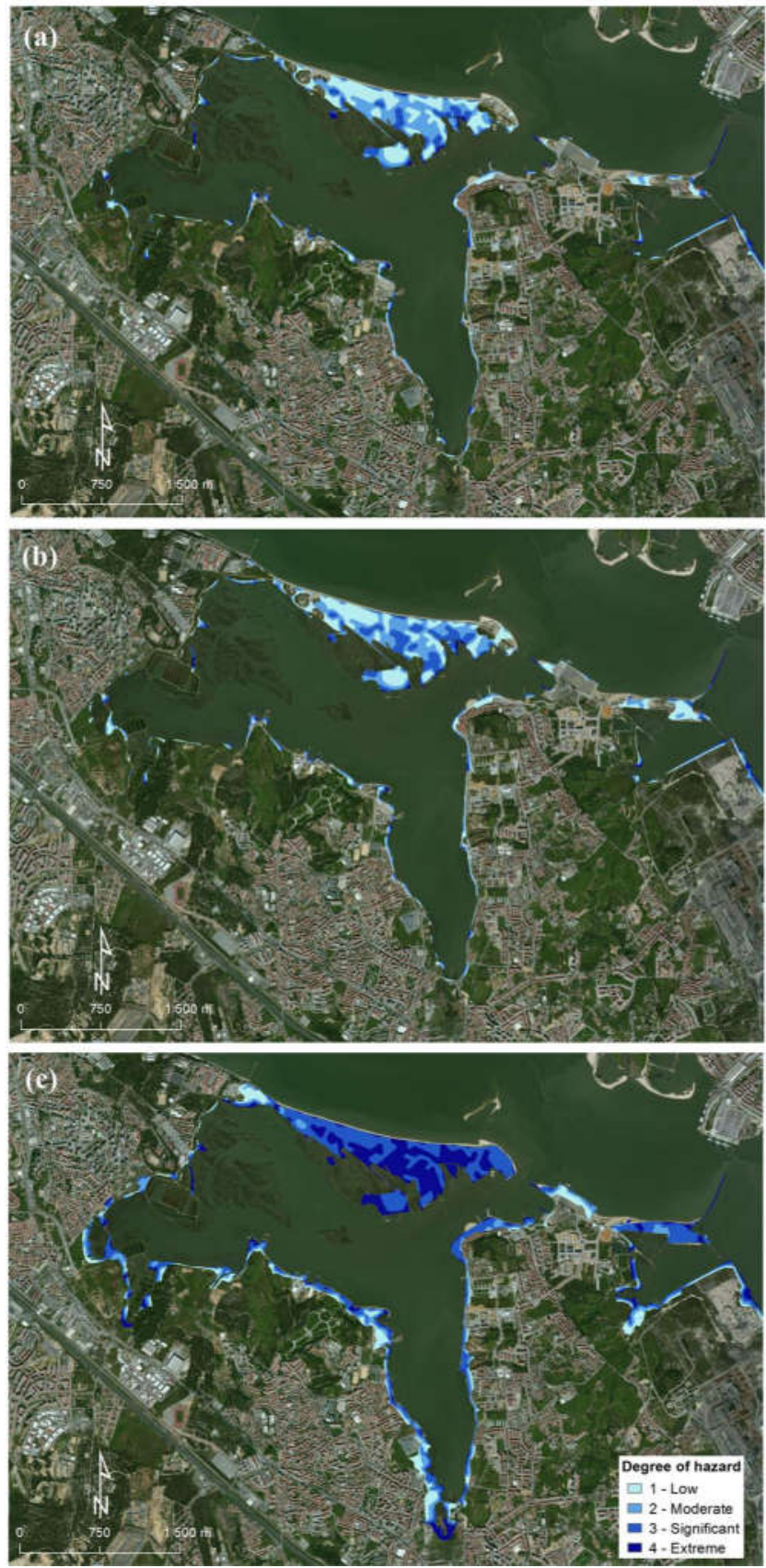

Fig. 8 Flood hazard index classification for different scenarios: a 20-year return period; b 100-year return period; c 100-year return period with sea level rise (image: ESRI Aerial Imagery) 
Table 7 Area (hectares) by class of vulnerability in each of the input assessment parameters in the Seixal waterfront area, in the three considered flooding scenarios

\begin{tabular}{|c|c|c|c|c|c|c|}
\hline & Very low & Low & Moderate & High & Very high & $\begin{array}{l}\text { Absence of } \\
\text { elements }\end{array}$ \\
\hline \multicolumn{7}{|l|}{ Road network } \\
\hline 20 -year flood & 4.717 & 6.576 & 2.130 & 1.705 & 0.249 & 77.357 \\
\hline 100-year flood & 5.088 & 6.971 & 2.210 & 1.742 & 0.277 & 83.887 \\
\hline SLR 100-year flood & 12.852 & 14.697 & 7.937 & 3.161 & 0.965 & 156.814 \\
\hline \multicolumn{7}{|l|}{ Built areas } \\
\hline 20-year flood & 5.855 & 1.972 & 1.445 & 0.978 & 0.593 & 81.774 \\
\hline 100-year flood & 6.899 & 2.527 & 1.870 & 1.110 & 0.797 & 86.973 \\
\hline SLR 100-year flood & 14.071 & 7.332 & 5.006 & 3.551 & 2.804 & 163.662 \\
\hline \multicolumn{7}{|l|}{ Mobility parameter } \\
\hline 20-year flood & 8.400 & 2.502 & 1.149 & 0.344 & 0.000 & 80.222 \\
\hline 100 -year flood & 10.680 & 2.680 & 1.230 & 0.433 & 0.000 & 85.152 \\
\hline SLR 100-year flood & 24.425 & 7.926 & 4.648 & 2.348 & 0.765 & 156.313 \\
\hline \multicolumn{7}{|c|}{ Concentration areas' parameter } \\
\hline 20-year flood & 0.000 & 0.819 & 0.000 & 0.092 & 0.000 & 91.707 \\
\hline 100-year flood & 0.000 & 0.847 & 0.000 & 0.092 & 0.000 & 99.236 \\
\hline SLR 100-year flood & 0.000 & 6.684 & 0.000 & 0.705 & 0.000 & 189.036 \\
\hline \multicolumn{7}{|c|}{ Environmental infrastructures } \\
\hline 20-year flood & 0.000 & 0.000 & 0.000 & 0.000 & 0.000 & 92.618 \\
\hline 100 -year flood & 0.000 & 0.000 & 0.000 & 0.028 & 0.000 & 100.147 \\
\hline SLR 100-year flood & 0.716 & 0.478 & 0.304 & 0.028 & 1.193 & 193.707 \\
\hline \multicolumn{7}{|c|}{ Area vulnerability $\left(A_{v}\right)$} \\
\hline 20 -year flood & 14.643 & 7.902 & 2.645 & 1.339 & 0.399 & 65.690 \\
\hline 100-year flood & 16.691 & 8.997 & 2.853 & 1.400 & 0.492 & 69.742 \\
\hline SLR 100-year flood & 34.151 & 20.441 & 7.488 & 5.481 & 4.659 & 124.206 \\
\hline \multicolumn{7}{|c|}{ People vulnerability $\left(\mathrm{P}_{\mathrm{V}}\right)$} \\
\hline 20-year flood & 0.000 & 76.705 & 4.667 & 9.704 & 1.542 & 0.000 \\
\hline 100-year flood & 0.000 & 80.138 & 5.894 & 12.578 & 1.565 & 0.000 \\
\hline SLR 100-year flood & 4.368 & 129.850 & 26.996 & 31.505 & 3.707 & 0.000 \\
\hline \multicolumn{7}{|c|}{ Vulnerability index $\left(\mathrm{I}_{\mathrm{V}}\right)$} \\
\hline 20-year flood & 14.425 & 7.557 & 3.356 & 1.199 & 0.391 & 65.690 \\
\hline 100 -year flood & 16.392 & 8.662 & 3.634 & 1.331 & 0.414 & 69.742 \\
\hline SLR 100-year flood & 32.749 & 20.515 & 10.219 & 6.621 & 2.115 & 124.206 \\
\hline
\end{tabular}

classification, is presented. Road network, built areas, mobility, concentration areas and environmental infrastructures are processed and summarized in area vulnerability $\left(A_{V}\right)$.

The adopted methodology helps in identifying the effects of flooding on both areas with residing and transient population and activities, thus identifying areas that could be affected by both direct and indirect impacts. For example, areas covered by the mobility parameter - which considers vehicles and bus stop locations - are in general higher than areas occupied by buildings, although mostly classified with very low vulnerability. 
In between flooding scenarios, the major differences in flooded areas are observed when sea level rise is considered.

$\mathrm{I}_{\mathrm{V}}$ is in general very low in all the scenarios considered: $0.14,0.16$ and $0.33 \mathrm{~km}^{2}$ in the 20-year, 100-year and SLR 100-year, respectively. Also, significant areas threatened by flooding show the absence of exposed elements.

Nevertheless, the distribution of $\mathrm{I}_{\mathrm{V}}$ by classes of flood hazard index ( $\mathrm{I}_{\mathrm{h}}$ ) must be considered, because hazard characteristics are not homogeneous in all the flooded areas, justifying therefore the consideration of flood height and velocity in $\mathrm{I}_{\mathrm{h}}$. This analysis (Table 7) shows that the most vulnerable areas (classes high and very high of $I_{V}$ ) present irregular distributions by Ih class, in each of the three scenarios, with some similarities between the 20-year and 100-year flood scenarios for the present MSL, in opposition to the SLR 100-year flood scenario. This behaviour is explained by the fact that human presence (buildings, road networks and infrastructures) often increases with the distance to the shoreline, resulting in that the majority of such areas are only under flood hazard in this last scenario. In both cases, the two higher classes of vulnerability (high and very high) consist of small areas -0.016 and $0.017 \mathrm{~km}^{2}$ in the scenarios without SLR and 0.087 $\mathrm{km}^{2}$ in the scenario with SLR.

In accordance with these figures, relevant areas where flood hazard manifests do not present a vulnerability score, i.e. do not overlay with areas where the typology of exposed elements used in the evaluation of area vulnerability $\left(A_{v}\right)$ is found: 0.657 in $0.926 \mathrm{~km}^{2}(71$ $\%)$ in the 20-year scenario; 0.697 in $1.002 \mathrm{~km}^{2}(69.6 \%)$ in the 100 -year scenario; and 1.242 in $1.964 \mathrm{~km}^{2}(63.2 \%)$ in the SLR 100-year scenario (Table 8).

Results presented in Fig. 9 demonstrate such an approach, namely in the areas that resident and transient population use, but where building densities and road network density are low or even absent (for locations see Fig. 5): for leisure, the Alfeite sand spit; for daily commutation, the parking lot of the fluvial station (Transtejo pier); for working, the facilities of the Portuguese Hydrographic Institute (close to Transtejo pier). In fact, flood hazard is affecting essentially functions and not so much residential areas, as the consideration of parameters related to mobility and concentration areas proved adequate in identifying vulnerability.

Nevertheless, the areas with higher vulnerability combine both fixed and transient occupancy of the territory, as is exemplified by the $I_{V}$ classification in the Seixal old city centre (Fig. 9), which is classified as vulnerable by both components of $\mathrm{I}_{\mathrm{V}}$-people $\left(\mathrm{P}_{\mathrm{V}}\right)$ and area vulnerability $\left(A_{V}\right)$.

\subsection{Risk index}

As a product of the vulnerability ( $\mathrm{I}_{\mathrm{V}}$ ) and hazard ( $\mathrm{Ih}_{\mathrm{h}}$ ) indexes, the risk index ( $\mathrm{Ir}_{\mathrm{r}}$ ) is maxi-mum where very high values of $I_{V}$ and $I_{h}$ coincide. In the 20-year flood scenario (Fig. 10a), the areas classified with very high risk are located in two particular spots: a commercial and residential building block in the Seixal old city centre (OCC), with a vital road section that connects the eastern and western sectors of the study area, a part of the building and dock that compose the fluvial station. In the 100-year flood scenario (Fig. 10b), the same classification of $\mathrm{I}_{\mathrm{r}}$ is quite similar to the 20-year scenario, only identifying an additional area inside the OCC with the same vulnerability characteristics. A different expression of the very high risk class is observed in the 100-year flood scenario with SLR (Fig. 10c), with a much larger area represented in the OCC - areas that were classified as of high and moderate $\mathrm{Ir}$, or not affected at all in the scenarios without SLR - along with the identifi-cation of a small part of the Amora dwelling located near the waterfront, crossed by a vital 
Table 8 Vulnerability index ( $\left.\mathrm{I}_{\mathrm{V}}\right)$ classification in the considered scenarios, by area (hectares) and relative frequency by hazard index $\left(\mathrm{I}_{\mathrm{h}}\right)$

\begin{tabular}{|c|c|c|c|c|c|c|c|c|}
\hline & & \multicolumn{5}{|l|}{$\mathrm{I}_{\mathrm{V}}$ class } & \multirow[t]{2}{*}{$\mathrm{I}_{\mathrm{V}}=0$} & \multirow{2}{*}{$\begin{array}{l}\text { Total } \\
\text { (ha) }\end{array}$} \\
\hline & & $\begin{array}{l}\text { Very } \\
\text { low }\end{array}$ & Low & Moderate & High & $\begin{array}{l}\text { Very } \\
\text { high }\end{array}$ & & \\
\hline \multirow[t]{6}{*}{ 20-year flood } & Total (ha) & 14.354 & 7.586 & 3.397 & 1.199 & 0.391 & 65.690 & 92.618 \\
\hline & \multicolumn{8}{|c|}{$\%$ of $I_{V}$ by $I_{h}$ class } \\
\hline & 1 & 39.4 & 27.4 & 14.9 & 38.6 & 76.4 & 28.3 & \\
\hline & 2 & 36.9 & 35.6 & 42.1 & 21.2 & 6.8 & 44.3 & \\
\hline & 3 & 19.4 & 33.5 & 35.2 & 31.4 & 16.8 & 21.4 & \\
\hline & 4 & 4.3 & 3.5 & 7.8 & 8.9 & 0.0 & 6.0 & \\
\hline \multirow[t]{6}{*}{ 100-year flood } & Total (ha) & 16.321 & 8.691 & 3.676 & 1.331 & 0.414 & 69.742 & 100.175 \\
\hline & \multicolumn{8}{|c|}{$\%$ of $\mathrm{I}_{\mathrm{V}}$ by $\mathrm{I}_{\mathrm{h}}$ class } \\
\hline & 1 & 36.6 & 25.1 & 16.5 & 42.5 & 77.7 & 23.3 & \\
\hline & 2 & 36.6 & 36.9 & 30.9 & 14.9 & 0.0 & 41.0 & \\
\hline & 3 & 22.8 & 34.3 & 43.1 & 34.6 & 22.3 & 29.2 & \\
\hline & 4 & 4.0 & 3.7 & 9.5 & 8.0 & 0.0 & 6.5 & \\
\hline \multirow{6}{*}{$\begin{array}{l}\text { SLR 100-year } \\
\text { flood }\end{array}$} & Total (ha) & 32.679 & 20.544 & 10.261 & 6.530 & 2.206 & 124.206 & 196.425 \\
\hline & \multicolumn{8}{|c|}{$\%$ of $I_{V}$ by $I_{h}$ class } \\
\hline & 1 & 8.0 & 13.2 & 25.0 & 23.1 & 5.0 & 13.2 & \\
\hline & 2 & 9.6 & 13.7 & 17.0 & 26.8 & 8.8 & 8.6 & \\
\hline & 3 & 50.5 & 46.1 & 34.4 & 37.7 & 82.0 & 39.8 & \\
\hline & 4 & 31.9 & 27.0 & 23.6 & 12.4 & 4.2 & 38.4 & \\
\hline
\end{tabular}

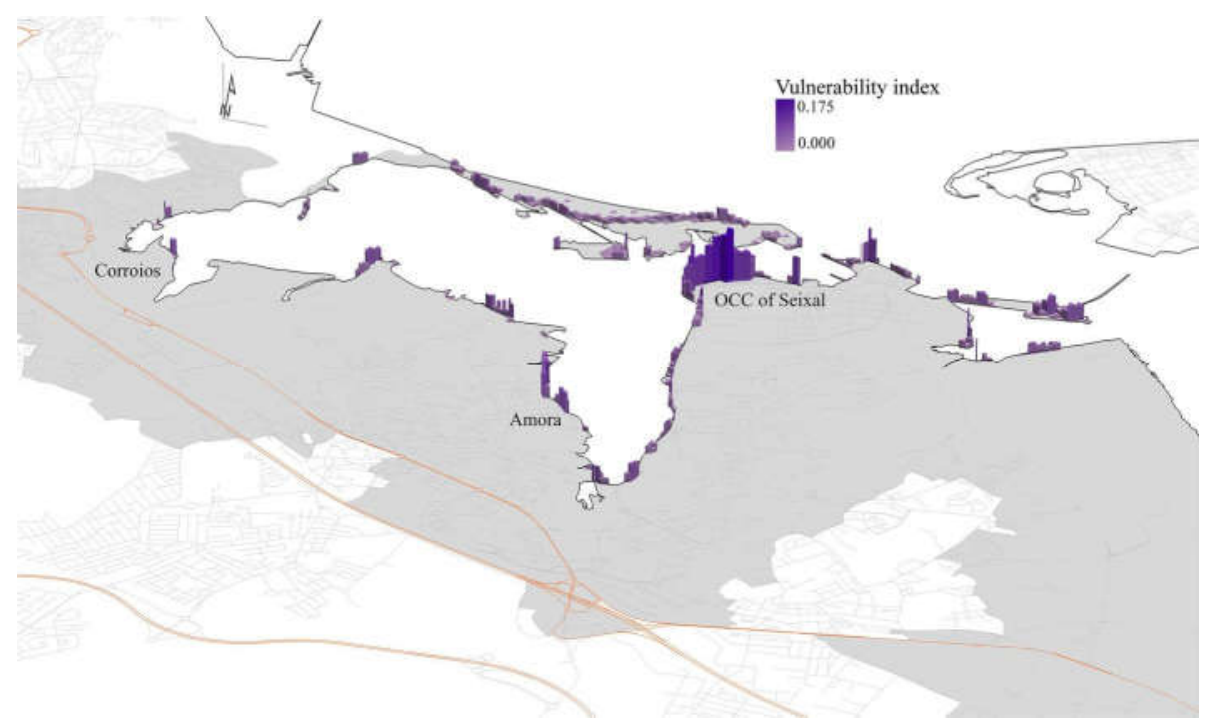

Fig. 9 Vulnerability index in the Seixal Municipality (in grey) for the 100-year return period scenario 

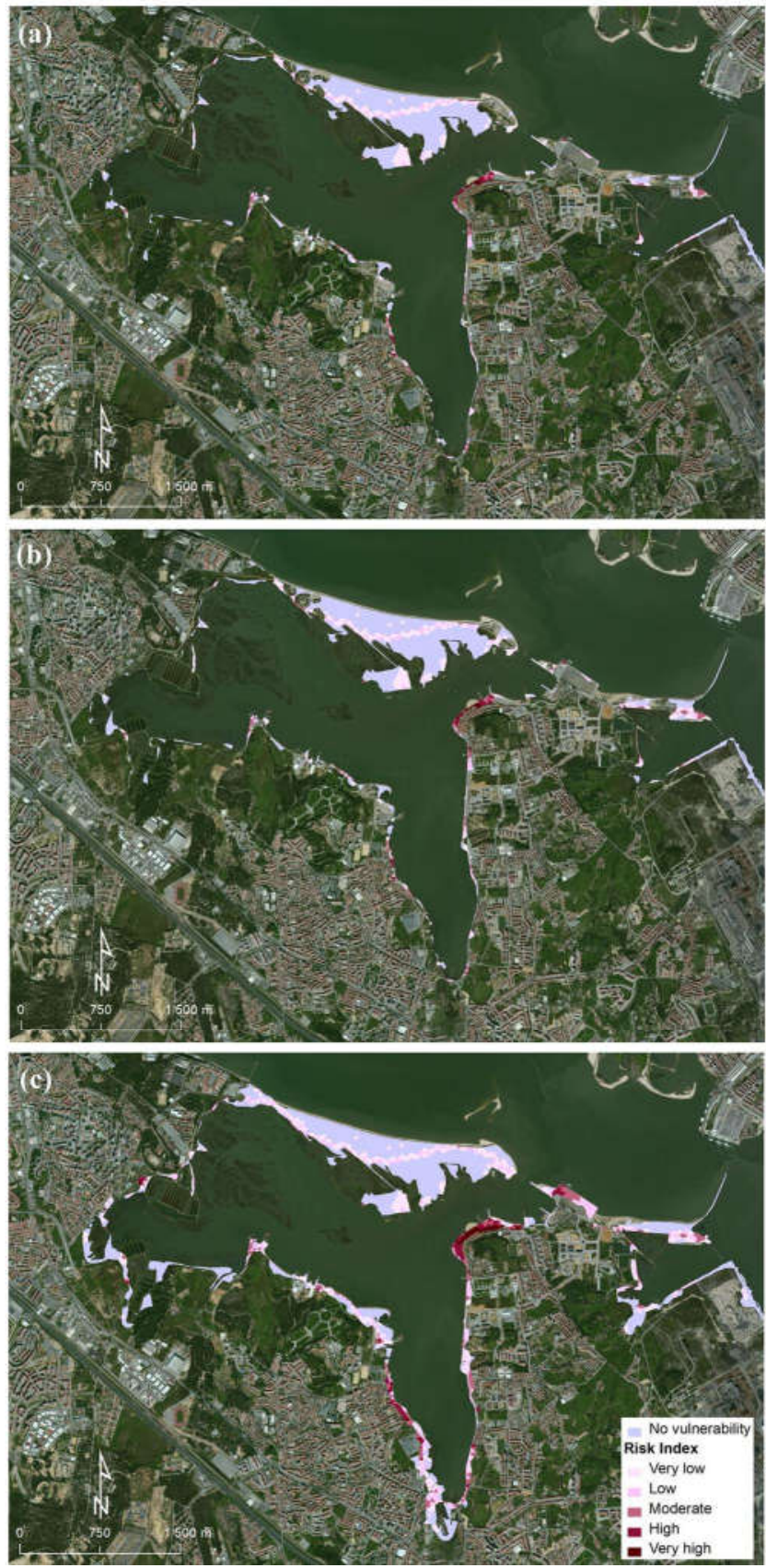

Fig. 10 Flood risk index classification for different scenarios: a 20-year return period; b 100-year return period; c 100-year return period with sea level rise (image: ESRI Aerial Imagery) 
road infrastructure and parking lot. The area inside the OCC with higher risk partly coincides with the limits of the statistical block with the higher classification in the people vulnerability $\left(\mathrm{P}_{\mathrm{V}}\right)$ parameter. In all the flooding scenarios, large areas where flood hazard exists are not overlaid by areas with exposed elements (expressed as no vulnerability in Fig. 10).

In general, the existence of buildings, road network and vehicles are common factors in areas with high and very high risk. Particular spots are equally classified, corre-sponding to the fluvial station and respective parking lot, and shipyards and buildings related to the naval industry, and a wastewater treatment facility, the last one only affected in the scenario considering SLR (upper left area in Fig. 10c). The risk profile of areas with higher classes of $\mathrm{I}_{\mathrm{r}}$ highlights the relevance of mobility and transport planning, the protection and contingency of economic activities and the concern with the more vulnerable population.

\section{Decision-making support}

The flood risk assessment results at a local scale allowed the definition of a consistent strategy to support different levels of the decision-making process. To support emergency planning, an early warning system was implemented for the locations with the highest risk of flooding. Preventive actions for flood severity reduction and impact mitigation, based on land-use and occupation planning measures, are proposed.

\subsection{Critical points characterization}

Along the Seixal waterfront, eleven critical points are representative of the locations with the highest risk of flooding (e.g. the Seixal old city centre) or crucial locations for the road and fluvial connectivity functions (e.g. the Transtejo fluvial station, Amora) (Fig. 11). This information is relevant for the emergency planning, enabling to anticipate the required civil protection resources.

Each critical point represented in the early warning system refers to areas identified as critical in the exposed elements and vulnerability assessment. Table 9 resumes, for each point, the type of affected elements and socio-economic functions, in the flooding scenarios of 20- and 100-year return period at present MSL. The typology of the exposed elements in the critical points located closer to the flood-prone areas is similar for both scenarios, showing differences in the quantity of elements exposed as the number of buildings affected. A particularly vulnerable point is the road access in the Alfeite sand spit (\#1) as there is no alternative access to buildings, public and military infrastructures and piers.

Some critical points refer to areas with little or negligible residential and commercial occupation. In such areas, specific exposed elements and functions are affected: related to fluvial and maritime socio-economy (\#5, \#7 and \#10); related to aquaculture and fisheries (\#2, \#3 and \#4); related to the access to sand spits or road dead ends (\#1, \#2 and \#11), with a particular significance to the access to military facilities.

In contrast, the remaining three critical points (\#5, \#7 and \#10) refer to consolidated urban areas usually characterized by the presence of parking lots, vehicles and public gardens, along with residential and commercial buildings. Disruptions in the road networks are a type of affected function which is common to almost all the critical points. 


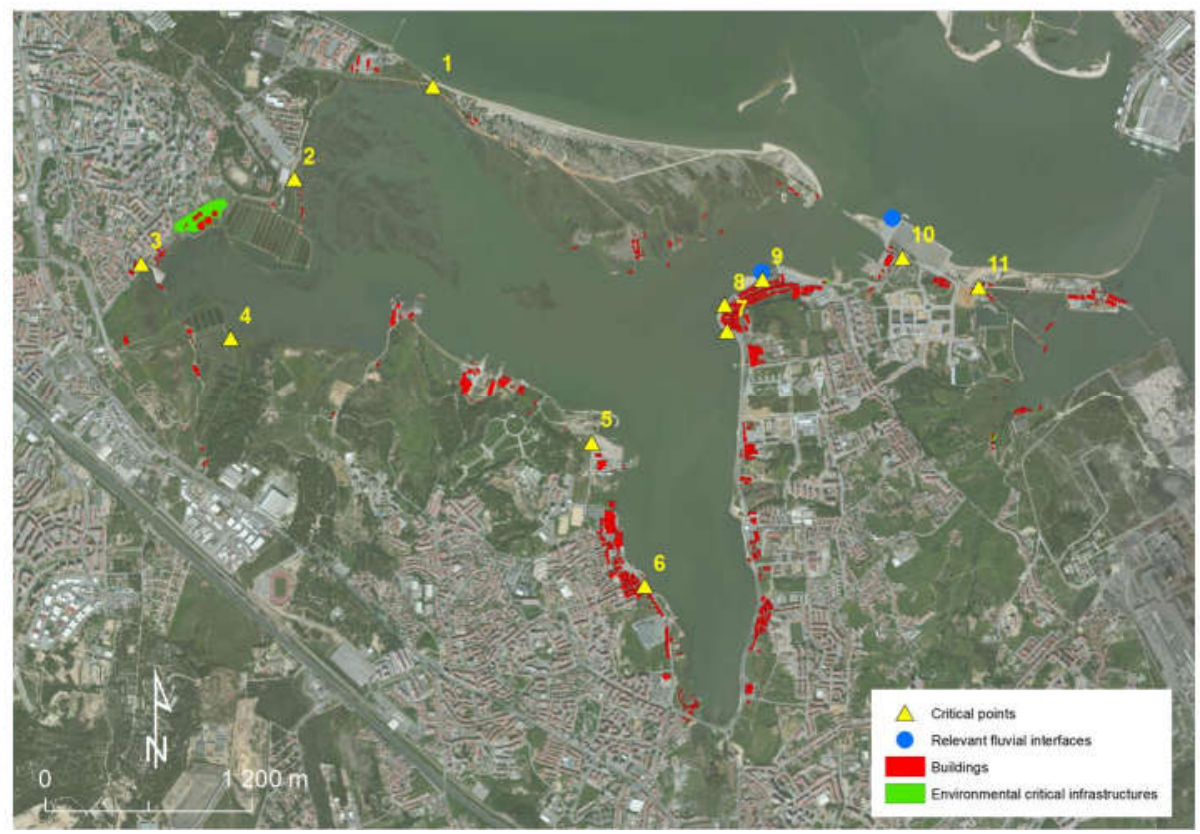

Fig. 11 Critical points for the flood early warning system and potential affected elements (image: ESRI Aerial Imagery)

\subsection{Early warning and emergency planning guidelines}

The previous results brought significant advances in the knowledge regarding flooding in the Tagus estuary under the influence of tide, wind and storm surge conditions - its hazard process and respective exposed elements and vulnerability. Based on this, spatial planning and emergency guidelines for disaster risk reduction can be defined.

In terms of emergency planning, the acquired knowledge regarding the spatial expression and time recurrence and forecast of flooding events has allowed municipal civil protection authorities to define detailed procedures in terms of optimizing each civil protection agents' role in risk communication and emergency response.

\subsubsection{Early warning system}

An early warning system was built taking advantage of the detailed forecasts developed for the Seixal area. The objective was to disseminate timely useful information about the likely time and severity of the flood to the civil protection agents, for them to take effective action in response.

Products available at the WebGIS interface were created using information at the several critical points defined above, following the integration approaches: (1) overview of all early warnings, organized by parish geographical location and alert level (defined in 3.3) with direct access to detailed information of the critical points in each parish that fit in the selected alert range; (2) map view of the alert level at each critical point, along with the detailed prediction of this alert level in the 48-h forecast window (Fig. 12); (3) time series 
Table 9 Type of affected features and functions in the critical points

\begin{tabular}{|c|c|c|c|c|c|c|c|c|c|c|c|c|c|c|c|c|c|c|c|}
\hline \multirow[t]{2}{*}{ Critical point } & \multicolumn{2}{|c|}{ Dominant risk index class $^{\mathrm{a}}$} & \multicolumn{17}{|c|}{ Type of affected features and functions ${ }^{b}$} \\
\hline & 20-year & 100-year & $\mathrm{RN}$ & $\mathrm{RB}$ & $\mathrm{CB}$ & $\mathrm{AB}$ & $\mathrm{CH}$ & W & PG & $\mathrm{V}$ & $\mathrm{P}$ & $\mathrm{D}$ & Sy & $\mathrm{S}$ & FS & FH & $\mathrm{Aq}$ & $\mathrm{Am}$ & M \\
\hline 1-Restinga do Alfeite & $\mathrm{VL} / \mathrm{L}$ & $\mathrm{VL} / \mathrm{L}$ & $\mathrm{x}$ & & $\mathrm{x}$ & & & & & & & $\mathrm{x}$ & & $\mathrm{x}$ & & & & & $\mathrm{x}$ \\
\hline 2 -Varejeira & $\mathrm{VL} / \mathrm{L}$ & $\mathrm{VL} / \mathrm{L}$ & & & & & & & & & & & & $\mathrm{x}$ & & $\mathrm{x}$ & & & \\
\hline 3-Ecomuseu Moinho & VL & VL & & & & & & & & & & & & & & & $\mathrm{x}$ & $\mathrm{x}$ & \\
\hline 4-Corroios & $\mathrm{VL} / \mathrm{L}$ & $\mathrm{VL} / \mathrm{L}$ & $\mathrm{x}$ & $\mathrm{x}$ & & & & $\mathrm{x}$ & & & & & & & & & $\mathrm{x}$ & & \\
\hline 5-Atalaia & $\mathrm{L} / \mathrm{M}$ & $\mathrm{L} / \mathrm{M}$ & $\mathrm{x}$ & & & & & & & & & $\mathrm{x}$ & $\mathrm{x}$ & $\mathrm{x}$ & & & & & \\
\hline 6-Prac, a 5 de Outubro & $\mathrm{L} / \mathrm{M}$ & $\mathrm{L} / \mathrm{M}$ & $\mathrm{x}$ & $\mathrm{x}$ & $\mathrm{x}$ & & & $\mathrm{x}$ & $\mathrm{x}$ & $\mathrm{x}$ & & $\mathrm{x}$ & & $\mathrm{x}$ & & & & & \\
\hline 7-Curva da Mundet & $\mathrm{M} / \mathrm{H}$ & $\mathrm{M} / \mathrm{H}$ & $\mathrm{x}$ & & & & & & & $\mathrm{x}$ & $\mathrm{x}$ & $\mathrm{x}$ & & $\mathrm{x}$ & & & & & \\
\hline 8-Igreja do Seixal & $\mathrm{H} / \mathrm{VH}$ & $\mathrm{H} / \mathrm{VH}$ & $\mathrm{x}$ & $\mathrm{x}$ & $\mathrm{x}$ & & $\mathrm{x}$ & & $\mathrm{x}$ & $\mathrm{x}$ & $\mathrm{x}$ & & & & & & & & \\
\hline 9-PCP do Seixal & $\mathrm{M} / \mathrm{H}$ & $\mathrm{M} / \mathrm{H}$ & $\mathrm{x}$ & $\mathrm{x}$ & $\mathrm{x}$ & & & & $\mathrm{x}$ & $\mathrm{x}$ & $\mathrm{x}$ & $\mathrm{x}$ & & $\mathrm{x}$ & & & & & \\
\hline 10-Terminal da Transtejo & $\mathrm{H} / \mathrm{VH}$ & $\mathrm{H} / \mathrm{VH}$ & & & & & & & & & & $\mathrm{x}$ & $\mathrm{x}$ & $\mathrm{x}$ & $\mathrm{x}$ & & & & \\
\hline 11- IH Azinheira & $\mathrm{VL} / \mathrm{L}$ & $\mathrm{L} / \mathrm{M}$ & $\mathrm{x}$ & & & $\mathrm{x}$ & & $\mathrm{x}$ & & $\mathrm{x}$ & $\mathrm{x}$ & & & & & & & & $\mathrm{x}$ \\
\hline
\end{tabular}

${ }^{a}$ VL very low; L low; M moderate; H high; VH very high

b RN road network; RB residential buildings; CB commercial buildings; AB administrative buildings; $\mathrm{CH}$ cultural heritage; W warehouses; PG public garden; V vehicles; P parking; D docks; Sy shipyard; S ships; FS fluvial station; FH fishery houses; Aq aquaculture; Am access to museum; M access to military facilities 


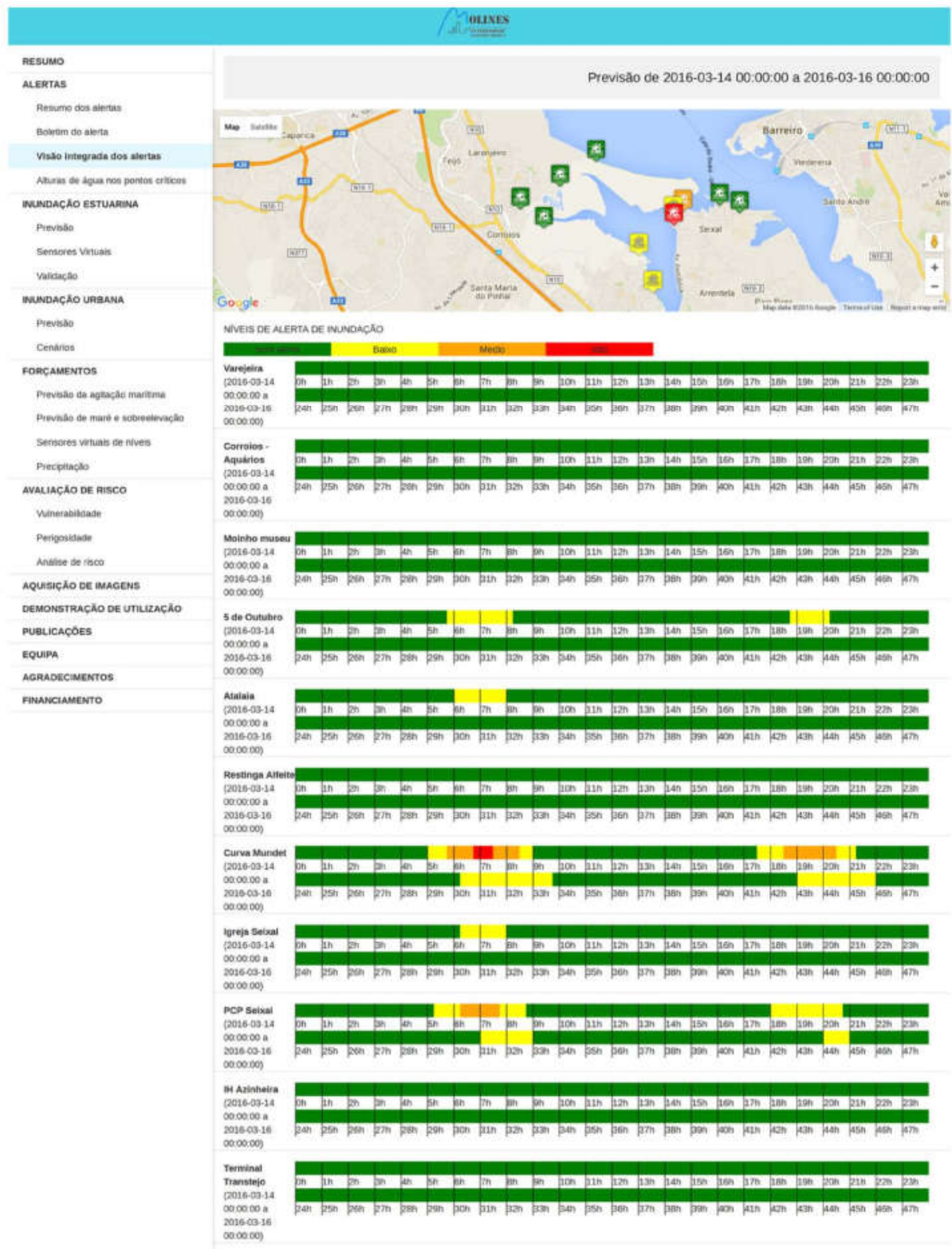

Fig. 12 Early warning detailed view for the Seixal Municipality: alerts for the critical points

of water heights at the critical points when the alert level exceeds the "no alert" threshold (Fig. 13). When the threshold of "no alert" is exceeded, the interface provides Web access to the early warning bulletin, which is also automatically sent by email to the relevant civil protection agents. The bulletin includes the relevant spatial and temporal information associated with the warning: map of the critical points; alert level at each critical point in 


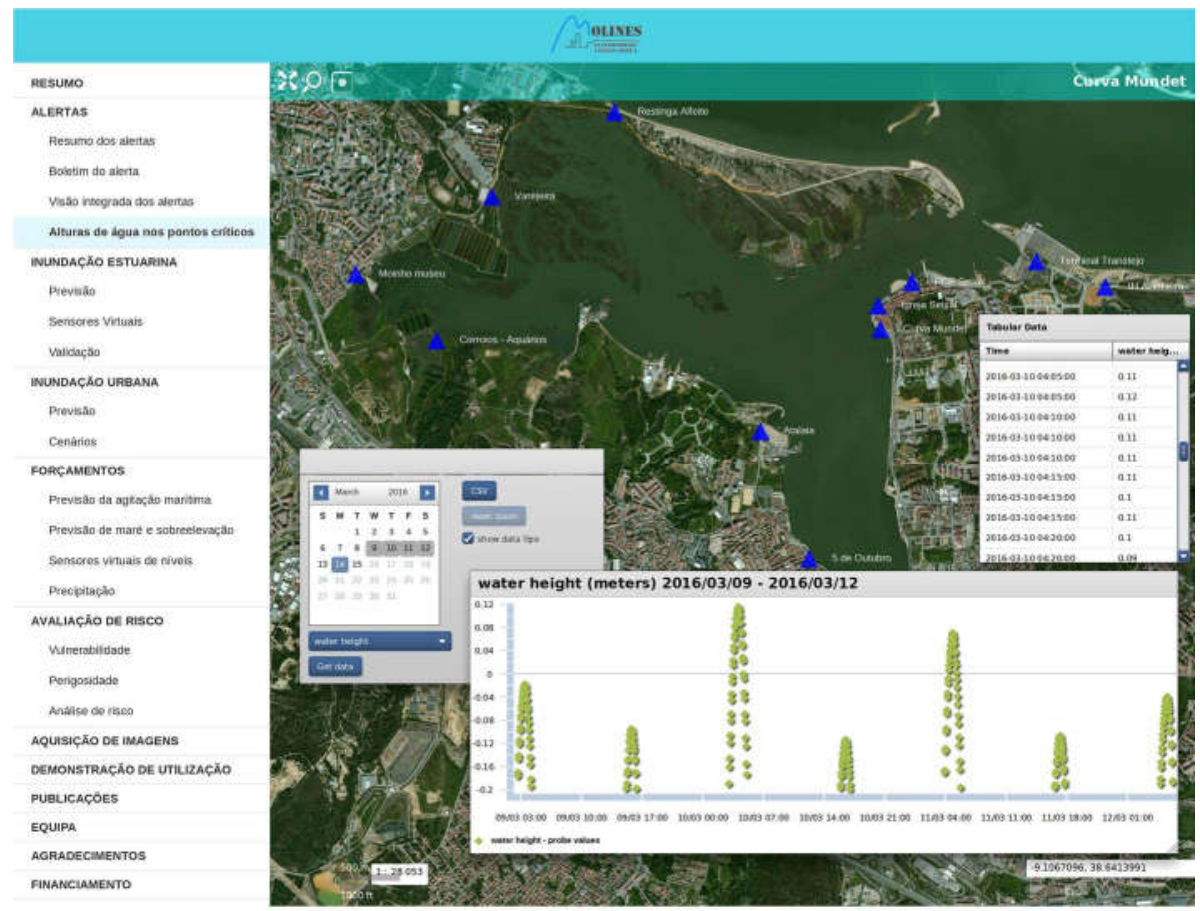

Fig. 13 Time series of water heights at the critical points

the 48-h forecast window; a summary of the maximum water height, wind intensity and atmospheric pressure during the same forecast window; information about each warning level (definition and possible impacts). The information provided by the interface assists civil protection agents to timely identify resources for the emergency response and to help take decisions to prevent flood damages and other indirect impacts.

\subsubsection{Emergency planning guidelines}

The definition of guidelines for the emergency planning is based on the data and tools previously obtained-in summary, the results of the risk assessment and the early warning system. The guidelines are sequenced accordingly to four emergency management stages (Fig. 14). As illustrated, the starting point for the entire process is the set-up of a list of monitoring routines with the objective of informing about present and predicted water levels and, when necessary, the subsequent dissemination for support of the following stages.

The sequence of stages is framed and structured by the Seixal Municipality emergency plan. Depending on the level of the alert, this planning instrument might be activated or not. In the same context, an evaluation of the capacity of municipal resources to deal with the imminence or factuality of an emergency is performed, following the standard procedures to be included in the emergency plan, and accordingly, supramunicipal resources are or not requested. 


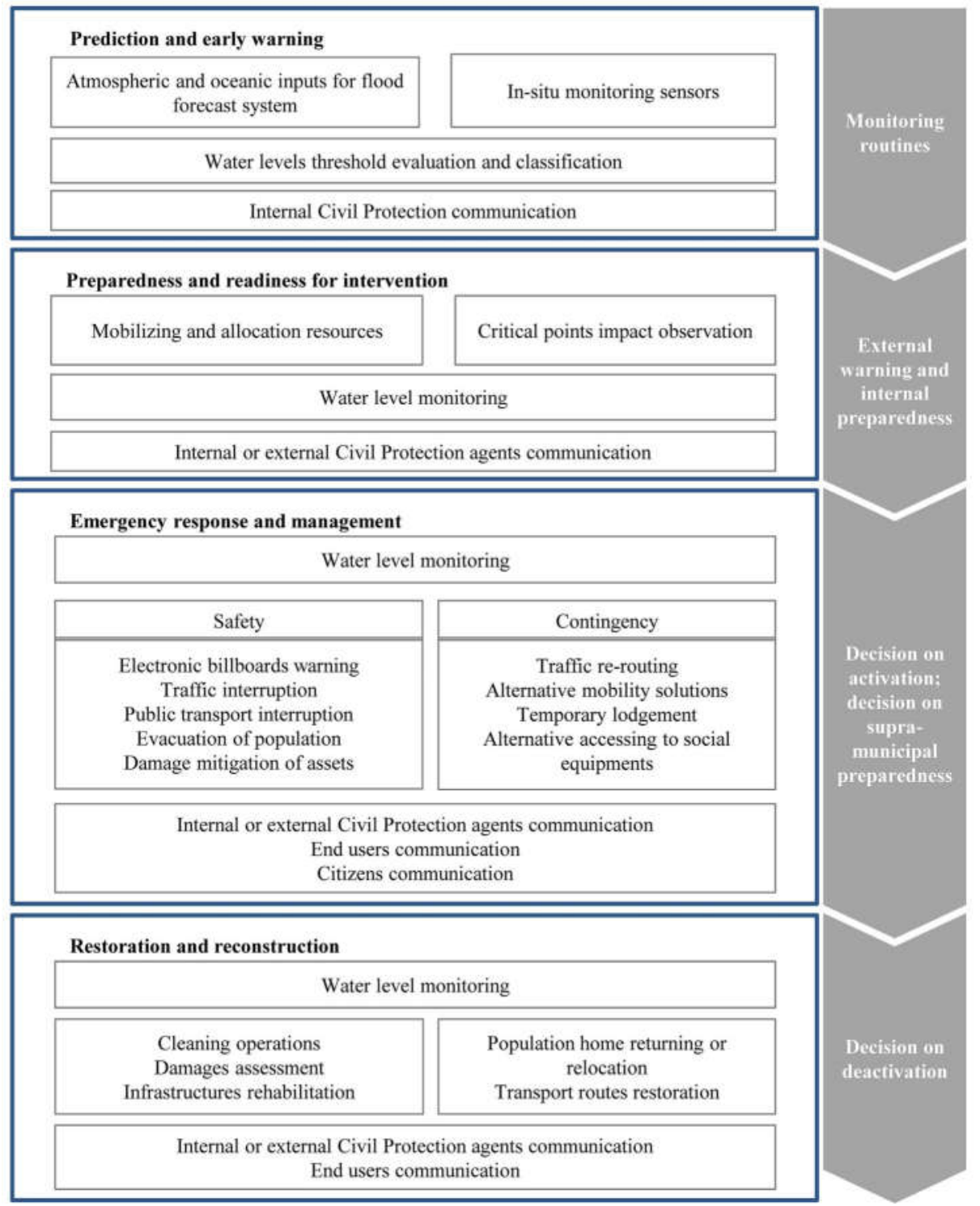

Fig. 14 Guidelines for the emergency management stages (in grey boxes: framing in the emergency plan)

Emergency response and management is devoted to ensuring the safety and contingency of people, functions and assets, with a focus on mobility. Transversally to all phases, the water levels are continuously monitored in order to support the decision of civil protection agents.

Finally, internal communication between civil protection agents is present in all stages. The involvement of other sectoral end-users (from the health, education, transport, economic or social fields) as well as communication to the citizens is foreseen and regulated in the emergency plan. This wider communication scope is limited to the last three stages described in Fig. 14- preparedness and readiness for intervention, emergency response 
and management and restoration and reconstruction-because in the prediction and early warning phase the information is conveyed uniquely between the municipal civil protection agents.

\subsection{Spatial planning guidelines}

Risk reduction from coastal flooding is becoming an increasingly difficult task. Urban waterfronts are coveted by real estate agents, as the value of prime locations and views over the estuary come at a premium. Former industrial and port areas present unique opportunities for centrally located urban development (ULI 2004; Brown 2008). At the same time, sea level is rising and posing an ever-increasing threat to urbanized shorelines and natural systems (Hallegatte et al. 2013; Fitzgerald et al. 2008; Nicholls and Cazenave 2010). Wetlands are now increasingly "squeezed" (Torio and Chmura 2013; Kirwan and Megonigal 2013) between rising sea waters and encroachment by flood defence infrastructures. While passive flood risk management has been appropriate in some contexts, future challenges will demand a more proactive adaptation stance.

In selecting the recommended planning guidelines for the Seixal waterfront, a set of 26 possible adaptation actions were identified, from the relevant literature (FLOODsite 2009; EEA 2013; Gersonius et al 2008; Wilby and Keenan 2012; Hallegatte 2009; Hamin and Gurran 2009; Poussin et al. 2012; Arkema et al 2013; CCAP 2011) and observation of local conditions along the Tagus Estuary. The 26 actions were then qualified according to their cost (low to high), the scale of intervention/scope (small/dwelling, to large/regional or national scale), the time horizon for full implementation (from short/less than 2 years to long/over 25 years) and regrets (no regrets being solutions that will provide benefits regardless of whether flood risk increases, whereas high regrets solutions are those that, if implemented, would adversely impact other measures of environmental performance or be too costly to revert).

The rating of each action is derived from the acquired experience with the Seixal/ Tagus estuary-specific situation and is naturally subjective and context dependent. For instance, some "soft" adaptation actions are relatively easy to approve in Portuguese legislation, since there is enough public/political support for them. In other contexts, such as the USA, changing or updating legal documents may be a much more strenuous effort, especially when land rights are involved (Eichenberg 2013; Davoren 1982). At the same time, some more costly structural measures would likely face serious financing constraints.

Based on these ratings and how adequate/easy to implement they would be for the specific context of Seixal, a subset of actions were selected to recommend as steps in increasing the resilience in face of coastal flooding and future sea level rise (Table 10).

Some of the actions indicated have already been completed (the Municipal Land-Use Plan of 2014, for instance, addresses the delimitation of vulnerable areas, limited the construction of basements and expanded the protection of wetlands), while other actions (such as the remodelling of waterfront public spaces so as to provide flood protection) would require future action. While quite a few of the actions (1-11) address problems already experienced during exceptional storm surges, others (12-19) should be part of a long-term strategy to minimize the impacts of expected sea level rise. All but four of the actions are considered as no- or low-regret, that is they provide multiple benefits and/or are beneficial even if the more adverse impacts of climate change do not materialize. 
Table 10 Selection of adaptation actions to coastal flooding and sea level rise in the municipality of Seixal

\begin{tabular}{|c|c|c|c|c|c|c|c|}
\hline & Action & $\begin{array}{l}\text { Time } \\
\text { horizon }\end{array}$ & Cost & Scale & Regrets & $\begin{array}{l}\text { Implemented } \\
\text { in Seixal? }\end{array}$ & Agents \\
\hline 1 & $\begin{array}{l}\text { Equip vulnerable dwellings with removable, fixed or } \\
\text { automatic flood gates for doors, windows, air holes } \\
\text { and garage doors }\end{array}$ & $1-2$ years & Low & Dwelling & Low & No & $\begin{array}{l}\text { Home and store owners } \\
\text { (installation), municipality and } \\
\text { parishes (supervision) }\end{array}$ \\
\hline 2 & $\begin{array}{l}\text { Implement formal system of road signs providing } \\
\text { warning of flooded roadways and sidewalks }\end{array}$ & $1-2$ years & Low & Dwelling & Low & No & $\begin{array}{l}\text { Municipality (installation), civil } \\
\text { protection agents (supervision) }\end{array}$ \\
\hline 3 & Protect existing wetlands, beaches and dune systems & $1-2$ years & Low & City/region & No & Yes & $\begin{array}{l}\text { Municipality (planning } \\
\text { instruments), environment agency } \\
\text { (management) }\end{array}$ \\
\hline 4 & $\begin{array}{l}\text { Identify safe routes alternative to flood-vulnerable } \\
\text { roadways and transit lines }\end{array}$ & $1-2$ years & $\begin{array}{l}\text { Low/ } \\
\text { medium }\end{array}$ & Block & No & Partially & $\begin{array}{l}\text { Municipality, civil protection } \\
\text { agents, public transportation } \\
\text { companies }\end{array}$ \\
\hline 5 & $\begin{array}{l}\text { Forbid the construction of basements in flood-prone } \\
\text { areas }\end{array}$ & $3-10$ years & Low & Dwelling & Low & Yes & Municipality \\
\hline 6 & $\begin{array}{l}\text { Forbid new construction in vulnerable areas through } \\
\text { local planning instruments }\end{array}$ & $3-10$ years & Low & Neighbourhood & Low & Partially & Municipality \\
\hline 7 & $\begin{array}{l}\text { Remove valuable or perishable items and sensitive } \\
\text { infrastructure from basements and flood-prone ground } \\
\text { floors }\end{array}$ & $3-10$ years & $\begin{array}{l}\text { Low/ } \\
\text { medium }\end{array}$ & Dwelling & Low & Partially & $\begin{array}{l}\text { Home and store owners } \\
\text { (implementation), municipality } \\
\text { (supervision) }\end{array}$ \\
\hline 8 & $\begin{array}{l}\text { Install water pumps on all basements, underground } \\
\text { garages, or ground floors below flood stage }\end{array}$ & $3-10$ years & $\begin{array}{l}\text { Low/ } \\
\text { medium }\end{array}$ & Dwelling & Low & No & $\begin{array}{l}\text { Municipality, home and store } \\
\text { owners }\end{array}$ \\
\hline 9 & $\begin{array}{l}\text { Implement early flood warning and monitoring systems } \\
\text { (SMS, media alerts, sirens, etc.) }\end{array}$ & $3-10$ years & $\begin{array}{l}\text { Medium/ } \\
\text { high }\end{array}$ & City/region & Low & Partially & Civil protection agents \\
\hline 10 & $\begin{array}{l}\text { Actively manage existing wetlands so as to increase } \\
\text { their resilience and promote their expansion }\end{array}$ & $3-10$ years & $\begin{array}{l}\text { Low/ } \\
\text { medium }\end{array}$ & Neighbourhood & No & No & $\begin{array}{l}\text { Environment agency (planning/ } \\
\text { managing), municipality } \\
\text { (assistance) }\end{array}$ \\
\hline 11 & $\begin{array}{l}\text { Map risks, highlight vulnerable areas, and increase } \\
\text { awareness }\end{array}$ & $3-10$ years & $\begin{array}{l}\text { Low/ } \\
\text { medium }\end{array}$ & Block & No & Yes & Municipality \\
\hline
\end{tabular}


Table 10 continued

\begin{tabular}{|c|c|c|c|c|c|c|c|}
\hline & Action & $\begin{array}{l}\text { Time } \\
\text { horizon }\end{array}$ & Cost & Scale & Regrets & $\begin{array}{l}\text { Implemented } \\
\text { in Seixal? }\end{array}$ & Agents \\
\hline 12 & $\begin{array}{l}\text { Transfer machinery, generators, elevator shafts to } \\
\text { higher floors }\end{array}$ & $3-10$ years & $\begin{array}{l}\text { Medium/ } \\
\text { high }\end{array}$ & Dwelling & Medium & No & $\begin{array}{l}\text { Home and store owners } \\
\text { (installation), municipality } \\
\text { (supervision) }\end{array}$ \\
\hline 13 & $\begin{array}{l}\text { Improve storm water drainage systems by replacing } \\
\text { pipes, introducing tidal valves, pumping stations or } \\
\text { reservoirs }\end{array}$ & $10-25$ years & $\begin{array}{l}\text { Medium/ } \\
\text { high }\end{array}$ & Neighbourhood & Low & Partially & Municipality \\
\hline 14 & $\begin{array}{l}\text { Raise waterfront parapets/guards to increase protection } \\
\text { against low flood levels or wave spillover }\end{array}$ & $10-25$ years & $\begin{array}{l}\text { Low/ } \\
\text { medium }\end{array}$ & Neighbourhood & Medium & No & Municipality \\
\hline 15 & $\begin{array}{l}\text { Raise waterfront public spaces and/or design them so as } \\
\text { to double as barriers against flooding }\end{array}$ & $10-25$ years & $\begin{array}{l}\text { Medium/ } \\
\text { high }\end{array}$ & Block & Medium & No & Municipality \\
\hline 16 & $\begin{array}{l}\text { Reduce peak surface runoff by introducing green } \\
\text { infrastructure and improving infiltration and detention }\end{array}$ & $10-25$ years & $\begin{array}{l}\text { Medium/ } \\
\text { high }\end{array}$ & Neighbourhood & Low & No & $\begin{array}{l}\text { Municipality (planning, major } \\
\text { features), home owners, parishes } \\
\text { (small features) }\end{array}$ \\
\hline 17 & $\begin{array}{l}\text { Enact changes to flood risk insurance policies so as to } \\
\text { increase accountability for "risky" location choices }\end{array}$ & $10-25$ years & High & City/region & High & No & Central government \\
\hline 18 & $\begin{array}{l}\text { Revise building standards so as to require higher ground } \\
\text { floor clearance on new buildings or reconstructions }\end{array}$ & $? 25$ years & Low & Neighbourhood & Low & No & Municipality \\
\hline 19 & $\begin{array}{l}\text { Create new artificial wetlands, namely by reconverting } \\
\text { underused reclaimed landfill areas }\end{array}$ & ?25 years & High & City/region & Low & No & $\begin{array}{l}\text { Ba1'a do Tejo society, environment } \\
\text { agency, South Bay project, } \\
\text { municipality }\end{array}$ \\
\hline
\end{tabular}




\section{Concluding remarks}

The management of flood risk in estuaries requires an integrated view considering the multiplicity of hazard-forcing factors acting in these systems, as well as their territorial and social complexity. An innovative approach to support flood risk management in estuaries is presented at a local scale. The approach is built upon a previous regional framework of the study area and integrates different methodological tools. Historical information contributes to support and validate the hazard assessment for different flooding scenarios based on numerical modelling. The exposed elements and territorial vulnerability assessments are integrated with the hazard results to support the comprehensive risk analysis at a local scale. Two levels of the decision-making process are addressed in this study: the early warning and emergency planning, and the reduction and impact mitigation. An early warning system implemented for the locations with the highest risk of flooding and a set of emergency planning guidelines will assist the municipal civil protection authorities in preparedness and emergency response. Increasing flood resilience actions, based on land-use and occupation measures, are proposed as possible contribution to territorial planning instruments.

The information and tools that result from this work enable decision-makers to address flood risk in estuaries at a local scale, contributing to their institutional capacity-building, and contributes to promote more resilient communities, fulfilling one of the Sendai Framework for Disaster Risk Reduction priorities.

Acknowledgments This work was funded by the Fundação para a Ciência e a Tecnologia (FCT), through the project MOLINES - modelling floods in estuaries from the hazard to the critical management (PTDC/ AAG-MAA/2811/2012). The authors thank the data provided by the projects DISASTER (PTDC/CS-GEO/ 103231/2008) and MorFeed (PTDC/AAC-AMB/100092/2008), also funded by FCT, and several institutions: Administração do Porto de Lisboa, Instituto Português do Mar e da Atmosfera, Agência Portuguesa do Ambiente, Direção Geral do Território, Autoridade Nacional de Proteção Civil, Câmara Municipal do Seixal and União das Freguesias de Seixal, Arrentela e Aldeia de Paio Pires.

\section{References}

Aerts JC, Lin N, Botzen W, Emanuel K, de Moel H (2013) Low-probability flood risk modeling for New York City. Risk Anal 33(5):772-788

Andrade C, Pires HO, Silva P, Taborda R, Freitas MC (2006) Zonas Costeiras. In: Santos FD, Miranda P (eds) Alterac,ões clima'ticas em Portugal. Cena'rios, impactes e medidas de adaptac,ão. Projecto SIAMII, Gradiva, Lisboa, pp 169-208

Andre' C, Monfort D, Bouzit M, Vinchon C (2013) Contribution of insurance data to cost assessment of coastal flood damage to residential buildings: insights gained from Johanna (2008) and Xynthia (2010) storm events. Nat Hazards Earth Syst Sci 13:2003-2012

Angeon V, Bates S (2015) Reviewing composite vulnerability and resilience indexes: a sustainable approach and application. World Dev 72:140-162

ARH do Tejo (2011) Plano de Gesta o da Regia o Hidrogra'fica do Tejo. S1'ntese para consulta pu'blica. Versa o Extensa ARH do Tejo, 462p. http://www.apambiente.pt/_zdata/Politicas/Agua/ParticipacaoPublica/ Documentos/ARHTejo/PGRH/2_PGRHTejo_versoextensa.pdf. Accessed 14 March 2016

Arkema KK, Guannel G, Verutes G, Wood SA, Guerry A, Ruckelshaus M, Kareiva P, Lacayo M, Silver JM (2013) Coastal habitats shield people and property from sea-level rise and storms. Nat Clim Change 3:913-918

Barriendos M, Ruiz-Bellet JL, Tuset J, Mazo'n J, Balasch JC, Pino D, Ayala JL (2006) The “Prediflood”, database of historical floods in Catalonia (NE Iberian Peninsula) AD1035-2013, and its potential applications in flood analysis. Hydrol Earth Syst Sci 18:4807-4823 
Bergstrand K, Mayer B, Brumback B, Zhang Y (2015) Assessing the relationship between social vulnerability and community resilience to hazards. Soc Indic Res 122(2):391-409

Bertin X, Li K, Roland A, Zhang Y, Breilh JF, Chaumillon E (2014) A modeling-based analysis of the flooding associated with Xynthia, central Bay of Biscay. Coast Eng 94:80-89

Breilh J-F, Bertin X, Chaumillon E, Giloy N, Sauzeau T (2014) How frequent is storm-induced flooding in the central part of the Bay of Biscay? Glob Planet Change 122:161-175

Brown P (2008) America's waterfront revival - port authorities and urban redevelopment. University of Pennsylvania Press, Philadelphia

CCAP (2011) The value of green infrastructure for urban climate adaptation. The Center for Clean Air Policy, http://ccap.org/assets/The-Value-of-Green-Infrastructure-for-Urban-Climate-Adaptation_ CCAP-Feb-2011.pdf. Accessed 14 March 2016

Cutter S, Boruff B, Shirley W (2003) Social vulnerability to environmental hazards. Soc Sci Quart 84:242261

Cutter SL, Barnes L, Berry M, Burton C, Evans E, Tate E, Webb J (2008) A place-based model for understanding community resilience to natural disasters. Glob Environ Change 18:598-606

David LM, Cardoso MA, Ugarelli RM, Bruaset S (2015) Chapter 4.12 New concepts and best management practices for mitigating impact of sea water level rise on drainage systems. In: Hulsman A, Gru"tzmacher G, van den Berg G, Rauch W, Jensen AL, Popovych V, Mazzola MR, VamvakeridouLyroudia LS, Savic DA (eds) Climate change, water supply and sanitation: risk assessment, management, mitigation and reduction. IWA Publishing, London, pp 318-323

Davoren WT (1982) Tragedy of the San Francisco Bay commons. Coast Zone Manage J 9(2):111

Defra/Environment Agency (2006) Flood and coastal defense R\&D programme. Flood risks to people. Phase 2. FD2321/TR2. Guidance Document, $82 \mathrm{p}$

EC (2014) European flooding costs could increase almost five-fold by 2050 . Science for environment policy: european commission DG environment news alert service, edited by SCU, the university of the West of England, Bristol. 15 May 2014 Issue 372. http://ec.europa.eu/environment/integration/research/ newsalert/pdf/372na7_en.pdf. Accessed 15 March 2016

EEA (2010) Mapping the impacts of natural hazards and technological accidents in Europe An overview of the last decade. EEA Technical report http:/www.eea.europa.eu/publications/mapping-the-impactsof-natural. Accessed 14 March 2016

EEA (2013) Adaptation in Europe: Addressing risks and opportunities from climate change in the context of socio-economic developments. European Environmental Agency-EEA technical report. http://www. eea.europa.eu/publications/adaptation-in-europe. Accessed 14 March 2016

Eichenberg T (2013) The challenges of adapting to climate change in San Francisco Bay. West-Northwest J Environ Law Policy 19:393

FitzGerald DM, Fenster MS, Argow BA, Buynevich IV (2008) Coastal impacts due to sea-level rise. Annu Rev Earth Planet Sci 36:601-647

FLOODsite (2009) Flood risk assessment and flood risk management. An introduction and guidance based on experiences and findings of FLOODsite (an EU-funded Integrated Project). Deltares Delft Hydraulics. http://www.floodsite.net/html/partner_area/project_docs/T29_09_01_Guidance_Screen_ Version_D29_1_v2_0_P02.pdf. Accessed 14 March 2016

Fortunato AB, Oliveira A, Baptista AM (1999) On the effect of tidal flats on the hydrodynamics of the Tagus estuary. Oceanol Acta 22(1):31-44

Fortunato AB, Rodrigues M, Dias JM, Lopes C, Oliveira A (2013) Generating inundation maps for a coastal lagoon: a case study in the Ria de Aveiro (Portugal). Ocean Eng 64:60-71

Fortunato AB, Costa, RT, Li K, Rogeiro J, Gomes J, Rilo A, Freire P, Oliveira A (2015) Sistema operacional de previsa o dos níveis extremos na costa Portuguesa. APRH (eds) VIII Congresso sobre Planeamento e Gesta o das Zonas Costeiras dos Pa1'ses de Expressa o Portuguesa 14-16 outubro de 2015, Universidade de Aveiro, 15 p. http://www.lnec.pt/fotos/editor2/dha/DHA\%20PDFs/fortunato_et_al_2015_ congresso_planeamento_gestao_zonas_costeiras.pdf. Accessed 22 March 2016

Fortunato AB, Li K, Bertin X, Rodrigues M, Miguez BM (2016) Determination of extreme sea levels along the Iberian Atlantic coast. Ocean Eng 111(1):471-482

Freire P, Jackson NL, Nordstrom KF (2013) Defining beaches and their evolutionary states in estuaries. J Coastal Res Spec Issue 65:482-487

Freire P, Tavares AO, Fortunato AB, Sa' L, Oliveira A, Rilo A, Santos PP (2015) Modelac, a o da inundac,ão em estua'rios. Da avaliac, a o da perigosidade a' gesta o crítica. APRH (eds) VIII Congresso sobre Planeamento e Gesta o das Zonas Costeiras dos Pai'ses de Expressa o Portuguesa 14-16 outubro de 2015, Universidade de Aveiro, 15 p. http://www.aprh.pt/ZonasCosteiras2015/pdf/3A5_Artigo_027.pdf. Accessed 15 March 2016 
Freitas JG, Dias JA (2013) 1941 windstorm effects on the Portuguese Coast. What lessons for the future? J Coastal Res Spec Issue 65:714-719

Gersonius B, Zevenbergen C, Puyan N, Billah NNN (2008) Efficiency of private flood proofing of new buildings-adapted redevelopment of a floodplain in The Netherlands. WIT Trans Ecol Environ 118:247-259

Guerreiro M, Fortunato AB, Freire P, Rilo A, Taborda R, Freitas MC, Andrade C, Silva T, Rodrigues M, Bertin X, Azevedo A (2015) Evolution of the hydrodynamics of the Tagus estuary (Portugal) in the 21 st century. Revista de Gesta o Costeira Integrada 15(1):65-80

Guillard-Gonc,alves C, Cutter SL, Emrich CT, Ze^zere JL (2014) Application of social vulnerability index (SoVI) and delineation of natural risk zones in greater Lisbon, Portugal. J Risk Res 18(1):651-674

Hallegatte S (2009) Strategies to adapt to an uncertain climate change. Glob Environ Change 19:240-247

Hallegatte S, Green C, Nicholls RJ, Corfee-Morlot J (2013) Future flood losses in major coastal cities. Nat Clim Change 3:802-806

Hamin EM, Gurran N (2009) Urban form and climate change: balancing adaptation and mitigation in the U.S. and Australia. Habitat Int 33:238-245

IPCC (2014) Climate change 2014: impacts, adaptation and vulnerability. Part B: Regional Aspects. In: Barros VR, Field CB, Dokken DJ, Mastrandrea MD, Mach KJ, Bilir BE, Chatterjee M, Ebi KL, Estrada YO, Genova RC, Girma B, Kissel ES, Levy AN, MacCracken S, Mastrandrea PR, White LL (eds) Contribution of working group II to the fifth assessment report of the intergovernmental panel on climate change. Cambridge University Press, Cambridge, United Kingdom and New York

Jongman B, Hochrainer-Stigler S, Feyen L, Aerts JCJH, Mechler R, Botzen W, Bouwer L, Pflug G, Rojas R, Ward P (2014) Increasing stress on disaster-risk finance due to large floods. Nat Clim Change 4:264-268

Kirwan ML, Megonigal JP (2013) Tidal wetland stability in the face of human impacts and sea-level rise. Nature 504:53-60

Kousky C, Shabman L (2015) Understanding flood risk decision making. Implications for flood risk communication program design. resources for the future http://www.rff.org/files/sharepoint/ WorkImages/Download/RFF-DP-15-01.pdf. Accessed 14 March 2016

Le Roy S, Pedreros R, Andre' C, Paris F, Lecacheux S, Marche F, Vinchon C (2015) Coastal flooding of urban areas by overtopping: dynamic modelling application to the Johanna storm (2008) in Ga`vres (France). Nat Hazards Earth Syst Sci 15:2497-2510

Miller A, Jonkman SN, Van Ledden M (2015) Risk to life due to flooding in post-Katrina New Orleans. Nat Hazards Earth Syst Sci 15:59-73

Morris BD, Foulsham E, Hanslow D (2013) An improved methodology for regional assessment of tidal inundation hazards in NSW estuaries. 21st Australasian Coasts \& Ports; Conference Proceedings. Sydney, pp 10-13 September 2013. https://search.informit.com.au/documentSummary; $\mathrm{dn}=$ 828946180884016;res=IELENG. Accessed 14 March 2016

Muir-Wood R (2011) The 1941 February 15th Windstorm in the Iberian Peninsula. Mapfre. http://www. mapfre.com/mapfrere/docs/html/revistas/trebol/n56/docs/Articulolen.pdf. Accessed 14 March 2016

Nicholls RJ, Cazenave A (2010) Sea-level rise and its impact on coastal zones. Science 328(5985):15171520

Oliveira PE, Ramos C (2002) Inundac,ões na cidade do Lisboa durante o se'culo XX e seus factores agravantes. Finisterra 74:33-54

Oliveira A, Jesus G, Gomes JL, Rogeiro J, Azevedo A, Rodrigues M, Fortunato AB, Dias JM, Tomas LM, Oliveira ER, Alves FL, den Boer S (2014) An interactive WebGIS observatory platform for enhanced support of coastal management. J Coast Res Spec Issue 70:507-512

Perrow C (2006) Disasters ever more? Reducing U.S. vulnerabilities. In: Rodriguez H, Quarantelli E, Dynes R (eds) Handbook of disaster research. Springer, New York, pp 521-533

Perrow C (2007) The next catastrophe: reducing our vulnerabilities to natural, industrial, and terrorist disasters. Princeton University Press, Princeton

Poussin JK, Bubeck P, Aerts JCJH, Ward PJ (2012) Potential of semi-structural and non-structural adaptation strategies to reduce future flood risk: case study for the Meuse. Nat Hazards Earth Syst Sci $12: 3455-3471$

Rilo A, Freire P, Guerreiro M, Fortunato AB, Taborda R (2013) Estuarine margins vulnerability to floods for different sea level rise and human occupation scenarios. J Coast Res Spec Issue 65:820-825

Rilo AR, Freire P, Santos PP, Tavares AO, Sa' L (2015) Historical flood events in the Tagus estuary: contribution to risk assessment and management tools. In: Pedofillini et al (eds) Safety and reliability of complex engineered systems, natural hazards. CRC Press, Taylor and Francis Group, London, pp $4281-4286$ 
Santos PP, Tavares AO, Ze^zere JL (2014) Risk analysis for local management from hydrogeomorphologic disaster databases. Environ Sci Policy 40:85-100

Santos PP, Tavares AO, Freire P, Fortunato A, Rilo A (2015) Territorial vulnerability to flooding in an estuarine area: Challenges valuing the structural and societal local. In: Podofillini et al (eds) Safety and reliability of complex engineered systems. CRC Press Taylor \& Francis Group, London, pp 4273-4280

Simonovic' SP (2012) Floods in a changing climate: risk management. Cambridge University Press, Cambridge

Tavares AO, Santos PP, Freire P, Fortunato AB, Rilo A, Sa' L (2015) Flooding hazard in the Tagus estuarine area: the challenge of scale in vulnerability assessments. Environ Sci Policy 51:238-255

Torio DD, Chmura GL (2013) Assessing Coastal Squeeze of Tidal Wetlands. J Coast Res 29(5):1049-1061

ULI (2004) Remaking the urban waterfront. Urban Land Institute, Washington DC

Vargas CIC, Oliveira FSBF, Oliveira A, Charneca N (2008) Ana'lise da vulnerabilidade de uma praia estuarina a' inundac,ão: aplicac, ão a’ restinga do Alfeite (estua'rio do Tejo). Revista de Gesta o Costeira Integrada 8(1):25-43

Ward PJ, Pauw WP, van Buuren MW, Marfai MA (2013) Governance of flood risk management in a time of climate change: the cases of Jakarta and Rotterdam. Environ Polit 22(3):518-536

Wilby RL, Keenan R (2012) Adapting to flood risk under climate change. Prog Phys Geog 36(3):348-378 Zhang

YJ, Baptista AM (2008) SELFE: a semi-implicit Eulerian-Lagrangian finite-element model for crossscale ocean circulation. Ocean Model 21(3-4):71-96

Zhang YJ, Stanev EV, Grashorn S (2016) Unstructured-grid model for the North Sea and Baltic sea: validation against observations. Ocean Model 97:91-108

\section{Cite this article as:}

Freire, P., Tavares, A.O., Sá, L. et al. Nat Hazards (2016) 84: 1705-1739.

doi:10.1007/s1 1069-016-2510-y 